\title{
Top incomes in East Africa before and after independence ${ }^{1}$
}

\author{
A B Atkinson, Nuffield College, Oxford and INET at the Oxford Martin School
}

1. Introduction: Top incomes in East Africa

2. An under-used source: income tax data

3. Putting the data in context: total population

4. The income taxpayers

5. The upper tail of the income distribution

6. Putting the data in context: control totals for income

7. Top income percentiles and shares

8. Conclusions

Appendices:
A. Sources of income tax data
B. Implications of the introduction of PAYE
C. Control totals for tax units and income
D. Sources for income control totals

\section{Introduction: Top incomes in East Africa}

This paper is concerned with the distribution of top incomes in former British colonial territories in East Africa: Kenya, Tanganyika/Tanzania, Uganda and Zanzibar. Its aim is to illuminate the position of colonial elites during the period of British rule and the extent to which they appropriated resources. Just how unequal were incomes? What was the distribution among the rich, mainly non-African, elite population? How did the position of the rich in these colonies compare with that of the rich in the United Kingdom? Secondly, how did income concentration evolve in the colonial period? Did inequality fall in the latter years of colonial rule, as the British government became more concerned with economic and social development? The third set of questions concerns the degree of inequality at independence. Tanzania became independent in 1961, followed by Uganda in 1962, and Kenya and Zanzibar in 1963. How far were there differences across different former colonies? Did some countries inherit a much more concentrated distribution, with implications for subsequent development? Were there differences between Kenya, where in 1949 the non-African population was 2.8 per cent, and Tanganyika and Uganda, where they were less than 1 per cent? Finally, the historical estimates provide a benchmark to consider the distribution of income

\footnotetext{
${ }^{1}$ The research for this paper has been supported by INET at the Oxford Martin School, where it forms part of the Programme for Economic Modelling (EMOD), and by the ESRC grant RES-16725-0640. I am most grateful to Facundo Alvaredo for suggesting a substantial re-structuring of the first version of this paper and to Friedrich Geiecke and Salvatore Morelli for their comments and assistance.
} 
in these countries today: Kenya, Tanzania (combining Tanganyika and Zanzibar) and Uganda.

The aim of this paper is to make use of a source that has been largely neglected - the tabulated income tax data - to see what can be extracted from these data in conjunction with control totals for population and total personal income. The results given here relate to a small group of the population, and are subject to many qualifications. The income tax data reflect the specific features of the tax system, and are much subject to avoidance and evasion. The control totals are only approximate. However, despite their limitations, the estimates based on income tax records have the advantage of providing one source of data on income inequality in a period about which little is known.

What evidence is there about the long-run evolution of income inequality in the four countries? Data for Kenya appeared in an early comparative table produced by Kuznets (1963), which showed the top income share in 1949. The UNU-WIDER database WIID shows Gini coefficients for preindependence Kenya for 1914, 1921, 1927, 1936, 1946, 1950, 1955 and 1960. The Gini coefficient was 63 per cent in 1936, 64 per cent in 1946, and then rose as high as 70 per cent in 1950. By 1955 it had fallen to 63 per cent again, but then rose to 68 per cent in 1960 . When, however, one goes back to the original sources, it may be seen that the apparent abundance of distributional data is misleading. The Kuznets figure was based solely on total non-African and African incomes, and tells us nothing about the inequality within these groups. The WIID data are from Bigsten (1986, Table 2), where the author describes the estimates as "very crude" (page 1159). They are in fact based on income categories, with an assumed lognormal distribution within each category. There are no underlying distributional data on incomes, and the assumption of a lognormal distribution may be particularly inappropriate for estimating the top of the distribution.

Even less in the way of data is available for the other countries. There are no WIID data for Tanzania before 1964, or for Uganda before 1970 (the endpoint of the series presented here), and no data at all for Zanzibar. There is therefore nothing on the colonial period. It is only in the post-independence years that there came to be (limited) information from household surveys and other sources. For example, the study by Huang for Tanzania using the 1969 Household Budget Survey found that the top 0.4 per cent of households received 9.2 per cent of total household income (1976, Table 1), or more than 20 times their proportionate share. This suggests a high degree of concentration, and the study pointed to the importance of the highly progressive tax system, with the group estimated to pay more than a quarter of their income in individual income tax.

The aim here is to investigate how far income tax data can be used to fill this gap in our knowledge. The tax data are described in Section 2. In his 
review of income distribution data for Africa, Phillips (1975) refers to the data contained in the annual reports of the East African Income Tax Department. As he notes, "these data are subject to known limitations of income data contained in income tax statistics, particularly incomplete coverage in terms of total income earners and of total incomes", but he describes the data as an "important source" (1975, page 18). One reason that they have been little exploited is that the income tax data can only be effectively employed in conjunction with independent control totals. In order to place the income taxpayers in context, we need information about the potential total size of the population. The problems that arise in estimating the population are discussed in Section 3, and the details of the methods are given in the Appendix. With the aid of the population totals, we examine in Section 4 the taxpaying population and their characteristics. Who were the taxpayers?

The distributional results are presented first in terms of the shape of the upper tail. The findings in Section 5 allow us to examine the degree of concentration and how it has changed over the colonial period and years immediately after independence. In order to produce results on income shares, a further set of control totals are needed: those for total income. The challenge of arriving at income totals is the subject of Section 6 . The results are presented in Section 7, which gives estimates of the top income shares. The main findings are summarised in Section 8.

\section{An under-used source: income tax data}

The first requirement is that a personal income tax be in operation. The personal income tax was first introduced in Kenya for Non-Natives in the Income Tax Ordinance of 1920 (Hailey, 1957, page 647), but "was soon repealed on account of strong opposition" (Vallibhoy, 1965, page 9). A graduated Non-Native Poll Tax was passed in 1933 (Report of the Commission appointed to enquire into and report on the financial position and system of taxation of Kenya, 1936, para 87), to be replaced by the income tax as such in May 1937. It was superseded in April 1940 by the Income Tax Ordinance, 1940, which introduced the income tax in the other East African territories and created the East African Income Tax Department. Under this legislation, each of the territories (Kenya, Tanganyika, Uganda and Zanzibar) had its own income tax law, but they were "for all practical purposes identical [allowing] the taxation in one territory only of the whole East African income and for the proceeds to be divided between the territories in which the income arose" (East African Income Tax Department, Annual Report for the year 1950, page 1). (In what follows, the report of this Department is referred to simply as "Annual Report" or AR.) The legislation was based on the Colonial Model Tax Ordinance, modified to meet local conditions. Among the "local conditions" 
were that in Uganda, but not the other three territories, Africans liable to pay poll tax were exempted from income tax (AR 1950, page 3).

The second requirement is that information be available about the distribution of taxpayers by income. The need for statistical data on income tax payers was recognised from the outset of the East African Department. As was observed in the 1951 Annual Report, "the absence of reliable statistics of income tax payers has added greatly to the difficulty of preparing Budget Estimates and of assessing the cost or yield of new tax proposals. A statistical system was introduced from the inception of Income tax but had unfortunately to be discontinued during the war" (page 4). The capacity to produce the required tabulations had indeed been demonstrated in Kenya by the information for 1936 and 1943 published in the Report of the Taxation Enquiry Committee Kenya 1947, Appendix 0. ${ }^{2}$ The tabulations were re-introduced in the early 1950s. From the Annual Report 1952 onwards, tax administrators published data on the distribution of taxpayers by ranges and amounts of "actual" income. Actual income is total income after permissible deductions, such as those for interest paid, passage money and losses incurred. The figures used are those for residents, but taxpayers dealt with by the Overseas Territories Income Tax Office in London are included. ${ }^{3}$ The sources of the income tax tabulations employed in this paper are given in Appendix Tables A.1 to A.4.

In the form that the income tax was introduced, an assessment was made in year $(\mathrm{t}+1)$ of the income accruing in year $\mathrm{t}$. The latter is referred to here as Income Year $\mathrm{t}$ (IYt). The income is that accruing in the calendar year (or, in the case of income from a trade, etc, the accounts year ending between $31^{\text {st }}$ March in the year and the next March $\left.31^{\text {st }}\right) .{ }^{4}$ As is explained in the 1951 Annual Report, "ideally, statistics should relate to the assessments for a particular year irrespective of the date when the assessment is made. As, however, an assessment may be made at any time within six years of the end of the year of assessment the delay in presenting final figures must always be considerable" (page 4). It is important to allow for delayed assessments, since these tend to be disproportionately self-employed individuals, whereas employees are assessed more promptly (see AR 1951, paragraph 31). In most

\footnotetext{
${ }^{2}$ Some figures for Kenya are contained in the distribution of incomes for persons paying the Non-Native Poll Tax in the Report of the Commission appointed to enquire into and report on the financial position and system of taxation of Kenya (1936, page 235). However only frequencies are given; there are no amounts; there are only four ranges; and the year (around IY1933) is not specified.

${ }^{3}$ In the case of individuals, these are mostly East African Government pensioners. In 1960 there were some 2,400 (AR 1960-61, para 21).

${ }^{4}$ This must be distinguished from the fiscal year, which was initially the calendar year, but in 1955 changed to the year ending $30^{\text {th }}$ June, so that in the transition period there was a fiscal "year" covering $1^{\text {st }}$ January 1954 to $30^{\text {th }}$ June 1955.
} 
cases, the tabulations used here were compiled a substantial period after the end of the assessment year: for example, for IY1949, assessed in 1950, the tables relate to assessments raised up to August 1953 (Annual Report 1953, Schedule 5).

There have been important changes in the income tax, notably the introduction of a PAYE system of deduction of tax at source from employment income with effect from $1^{\text {st }}$ July 1966 (see AR 1965-66, Note after para 7). The implications are described in Appendix B. The key point is that the additional surtax, chargeable at a graduated scale on chargeable income in excess of $£ 1,000$, continued to be assessed and payable after the end of the year. The tabulations continued therefore to provide information about the distribution of incomes at higher levels. However, in 1971, in Kenya the PAYE system was extended to cover the higher rates of tax, so that higher incomes are not included in the tabulations where tax was collected entirely by PAYE (AR 197172, para 1). As a result, the estimates here stop in 1970. The same applies to Tanzania and Uganda. In the case of Tanzania, data for 1974 were published by the Bureau of Statistics of Tanzania, rather than by the East African Income Tax Department, but the Bureau notes that "there are no comparable data for the previous years" (page 1). I have therefore not used these data. In Tanzania, there was a further discontinuity in 1966 when the figures for Zanzibar were amalgamated with those for Tanganyika. This has been taken into account in the construction of the control totals. In the case of Zanzibar, separate figures ceased to be published in 1965, but the statistics for that year and for 1964 do not appear comparable with earlier years, and have not been used.

The statistics employed here are a reflection of the underlying construction of the income tax, and this must qualify the conclusions drawn. The tax unit differs from the household, more commonly employed in the analysis of income distribution, and does not capture any wider grouping among whom income may be shared. A person in the top income groups may well, in the East African context, have had obligations to a wide range of people, so that the equivalent income may have been considerably lower than suggested by the tax unit calculation. Income as recorded in the tax returns may depart seriously from a full measure of economic resources. Some of the evident problems are discussed later in the paper. For example, the role of subsistence income is considered in Section 6. But the limitations of the data should be borne in mind throughout the paper.

\section{Putting the data in context: total population}

The people recorded in the income tax statistics have to be related to the population as a whole: the number if the income of everyone were to be 
assessed. The tax data relate to tax units, which may comprise, in addition to the taxpayer, a dependent spouse and children. The relevant total of tax units is therefore derived by subtracting the estimated number of children, defined as those aged under 15, and subtracting married women (including both legal and common-law marriages). This is of course an artificial construction, but its limited purpose is to provide a scaling factor.

The problems that arise in implementing this concept are described in turn for each of the countries.

\section{Kenya}

Prior to the late 1940s, little is known about the aggregate of population. Writing in 1947, Kuczyinski opened his chapter on the demography of Kenya by saying that "no census of the whole population has yet been taken. All censuses effected prior to 1931 comprised only the non-native population, while the census of 1931 included also a small fraction of the native population" (1949, page 127). Numbers such as the 3 million given for the native population at the time of the 1911 Census (quoted in Kuczysinki, 1949, page 144) seem to be have little firm basis. The inter-censal estimates for non-natives also appear unreliable. Kuczynski (1949, pages 148 and 149) describes as "quite puzzling" the fluctuations in the number of recorded Europeans during the Second World War and the 50 per cent increase in 1943 in the number of Asian origin. As a result, no use is made of the inter-censal figures. In 1948 separate censuses were held for the native and non-native populations, and there were subsequent censuses in 1962, 1969 and 1979 in the period covered here. The results are however surrounded by considerable uncertainty. According to Bondestam, "Kenya has one of the best population statistics in Africa" (1973, page 11), but the comparison of the censuses for 1962 and 1969 still shows "an unbelievably high growth rate" (page 11).

In the face of these difficulties, I have proceeded by anchoring the estimates in the series for total population starting in 1950 given by US Census Bureau International Database (referred to as USCB). (The link is http://www.census.gov/population/international/data/idb/informationgatewa y.php . This source used by Maddison (2003) in his studies of world growth, and it has the advantage of facilitating comparisons across countries. For Kenya, the series is close to the census totals for 1962 and 1969, but rather higher in 1979 (by 4.5 per cent). At the beginning of the series the difference is more marked: the 1950 USCB figure is 5.9 per cent higher than the figure for 1950 used by Bigsten (1986, page 51) based on the 1948 census total. The difference for 1950 complicates the backwards extrapolation to 1948-9, 1943 and 1936. For 1948 and 1949, the 1950 figure is extrapolated using the 1948 and 1949 totals given in the East African Statistical Department Bulletin, September 1958, page 3. For 1936 and 1943, the 1950 figure is extrapolated backwards 
using the (linearly interpolated) totals in Bigsten (1986, page 51), which are based on the work of Collier and Lal (1980, page 38). It should be emphasised that the estimates given here for 1936 and 1943 are surrounded by considerable margins of error.

The proportion of the population aged 15 and over is obtained from the UN The Size and Age Distribution of the World Populations 1994, page 482), which gives figures from 1950 at 5 yearly intervals, which have here been interpolated linearly. The interpolated UN figures for 1962, 1969 and 1979 are close to those from the censuses in those years (see also Mitchell, 2003, page 15). The proportions for 1936, 1943, 1948 and 1949 have been assumed equal to that in 1950 (60.2 per cent). In the 1969 population census, marital status was recorded and the number of married women was equal to 34.4 per cent of the population aged 15 and over (1969 Population Census, Volume IV, Analytical Report, Tables 1.2 and 8.1). This proportion has been assumed to apply to all years.

In 1948, of the recorded population in Kenya of 5.4 million, 29,660 were classified as European (or 0.55 per cent). By the census of 1962, the European population had growth faster than the total population, reaching 55,759 out of 8.6 million (or 0.64 per cent), of whom some 40,400 were aged 15 or over (Statistical Abstract (SA) 1976, page 12 and SA 1968, page 16). By the census of 1969 , the European population had fallen to 40,593 out of 10.7 million (or 0.38 per cent), of whom 30,200 were aged 15 or over (SA, 1976, pages 12 and 15). In the census of 1979, the European population was little changed at 39,901 out of 15.3 million (or 0.26 per cent) (SA, 1980, page 12).

\section{Tanganyika/Tanzania}

The total population figure until 1966 refers to Tanganyika/mainland Tanzania. The base series used here from 1950 is the USCB described above. The 1948 and 1949 totals (from the East African Statistical Department Bulletin, September 1958, page 3) are linked at 1950 to the USCB series (described above). The figures may be compared with those from the population censuses for 1948 and 1957 (see Lury, 1966, Appendix II). The series used here is 2.4 per cent higher in 1948 than the census total, in line with the evidence that the census total was too low by some 3 per cent (Bondestam, 1973, page 11). The difference in 1957 is rather larger (7.6 per cent) but not too far from that indicated by Bondestam, who suggests a census underenumeration by 5-6 per cent (1973, page 11). The population figures for the whole of Tanzania, including Zanzibar, from 1966 to 1970 are obtained by adding the total recorded for Zanzibar in the 1967 Census of population $(354,000)$ (Zanzibar Revolutionary Government, Statistical Abstract 1991, page 9). 
The age composition of the population was taken from the 5-year interval data in the United Nations The size and age distribution of the world populations (1994, page 810), interpolated linearly from 1950 to 1970 (and back to 1948 and 1949). (The same percentage is applied to the figures including Zanzibar.) Regarding marital status, questions were asked in the 1967 census. From volume 3 of the United Republic of Tanzania, 1967 population census, page 52, it can be calculated that in 1967 married women made up 39.1 per cent of those aged 15 and over. The latter proportion is assumed to apply to all years.

\section{Uganda}

The census taken in Uganda in 1948 by the newly-formed East African Statistical Department replaced large group enumeration in assemblies by a hut enumeration and a further 10 per cent sample of those enumerated. The resulting total population was reported in 1948 as 4,959,000, which implies a growth rate of some 2 per cent per year since 1931. There continued in 1959 to be separate censuses for the African and non-African populations, but in 1969 the census covered the whole population. The reported total populations were $6,538,000$ in 1959 and 9,548, 847 in 1969. The 1959 figure implied a growth rate of 2.5 per cent between 1948 and 1959; whereas the growth between 1959 and 1969 was at the rate of 3.9 per cent.

The 1948, 1959 and 1969 census figures may be compared with the figures contained in the USCB database. The 1969 figures are close: the USCB figure is 1 per cent lower. But the 1959 USCB figure is 8 per cent higher and that for 1950 is 11.4 per cent higher than the 1948 census figure. The USCB figures are therefore higher initially but indicate a slower annual population growth rate: 2.9 per cent. The UCSB figure for 1950, taken with the 1931 census figure, implies an annual growth rate of 2.4 per cent between 1931 and 1950. Given the possibility of under-enumeration in the early censuses, and the pattern of implied growth rates, the UCSB figures are used here. It should however be noted that they may overstate the population by some 10 per cent in the 1950s. The figures for 1948 and 1949 are from the East African Statistical Department Bulletin, September 1958, page 3, linked at 1950 to the USCB series.

The proportion of the population aged 15 and over is obtained from the UN The Size and Age Distribution of the World Populations 1994, page 482), which gives figures from 1950 at 5 yearly intervals, which have here been interpolated linearly (and back to 1948 and 1949). The interpolated UN figure for 1969 is close to that from the census (Report on the 1969 Population Census, volume III, page 68). The interpolated figure for 1959 is some 5 percentage points smaller than the census figure, which operates in the opposite direction from the choice of total population figure described above. 
The 1969 population census (Report on the 1969 Population Census, volume III, page 68) contains information on marital status, showing that married women represented 33.9 per cent of those aged 15 and over. This percentage has been assumed to apply throughout the period.

\section{Zanzibar}

Zanzibar is not included in the USCB database. The main basis for the figures used here are the population censuses conducted in 1948, 1958, and 1967. The totals for the first two years are given in Lury (1966, Appendix page 12); the 1967 figure is from Mitchell (1982, page 41). The figures for 1956 and 1957, and for 1959 to 1961, are from the Economic and Statistical Review, December 1961, Table B4. The figures for 1962 to 1964 are from the Economic and Statistical Review, March 1970, Table B2. The figures for other years are linearly interpolated. According to the 1948 census, of the total population of $264,162,199,975$ (76 per cent) were recorded as African. Of the 64,187 nonAfricans, the majority were Arab (44,560) or Indian (15,211). There were 296 Europeans.

The proportion of the population aged 15 and over in 1958 is given in the Report on the census of the population of the Zanzibar Protectorate, 1958, page 26. The proportion for 1967 is given in volume 3 of the United Republic of Tanzania, 1967 population census, page 55. These figures have been linearly interpolated between 1958 and 1967. The proportion in 1958 is assumed to apply to the earlier years 1948 to 1957 . The ratio of married women to the population aged 15 and over has been assumed equal to that in mainland Tanzania.

\section{Conclusion}

The population figures for colonial Africa are at best approximate, and should be interpreted with great care. But it should be remembered that they are only being used here for a limited object: they are designed to provide a sense of scale. The control totals used are given in Appendix C.

\section{The income taxpayers}

The empirical evidence presented here is based on the recorded incomes of those assessed for income tax. Who were these income taxpayers? From the level at which the tax threshold was set, it is evident that they were a 
extremely well-off minority. In East Africa, the threshold for a single taxpayer in 1951 was $£ 200$, which was more than three times average income in Uganda and more than six times that in Tanganyika. But what else do we know about the people who paid the colonial income tax? The statistical information about the operation of the income tax is limited, but provides some clues.

\section{A Non-African tax?}

First of all, were the East African taxpayers all Europeans? In principle, the tax was levied on all, Africans as well as non-Africans in all countries apart from Uganda, where Africans liable to pay poll tax were exempted from income tax (East African Income Tax Department, Annual Report for the year 1950, page 3). (The Ugandan exception continued until 1961 (Due, 1963, page 34).) It was however the non-African population that constituted the bulk of taxpayers. The size of this population varied across the countries. It was most significant in Zanzibar, where 17 per cent of the population in 1948 was Arab. Next at that time came Kenya with a non-African population of 2.9 per cent. This may be contrasted with Tanganyika, where there were 70,160 non-Africans out of 7.5 million and in Uganda where there were 40,965 out of 5.0 million (source: Digest of Colonial Statistics, September-October 1953, page 87). Both these figures were less than 1 per cent. It should be noted that Europeans were a minority among the non-African population: in Tanganyika there were 10,648 Europeans and in Uganda 3,448.

In the early years of the East African Income Tax, information was provided about the breakdown between European and "Asians and others", where the latter included Africans in the case of all except Uganda. Table 1 shows the breakdown by numbers of East African resident taxpayers assessed in IY1949. There are large differences. Europeans predominate in Kenya and Tanganyika, but there are more or less equal numbers of Europeans and Asians in Uganda, and in - the much smaller - Zanzibar, Europeans are a minority.

\section{Sources of income}

The tabulations in Table 1 distinguish between employees and "individuals", where the latter refer to self employed professionals and businessmen. Employees account for the majority of taxpayers, although in Zanzibar the figures are nearer parity. Among employees, Europeans predominate, particularly in Kenya and Tanganyika, so that in Kenya nearly two-thirds of all assessments are accounted for by European employees. The proportions of Europeans are smaller in Uganda (less than half) and Zanzibar (around one third). Among the self-employed, Asians (and others) predominate, with the proportions varying from 55 per cent in Kenya to over 90 per cent in Uganda and Zanzibar. At the same time, with the exception of 
Zanzibar, the average incomes of the self-employed Europeans are higher: in Kenya, they accounted for 27 per cent of the taxpayers but received 41 per cent of the assessed income.

The growth of the income tax

The proportion of total tax units paying income tax was small. In 1948, the percentage was 0.5 per cent (in Kenya) or less (the lowest being 0.15 per cent in Uganda). It may be seen from Figure 1 that the proportion increased over the rest of the colonial period. Between 1948 and 1964, ${ }^{5}$ the proportion doubled in Tanganyika and tripled in Uganda. In Kenya and Zanzibar, the proportion rose to around 1.5 per cent. In this context, it is worth remembering that in the early days of the US personal income tax (1913-1915), the corresponding proportion of taxpayers was 0.9 per cent (Piketty and Saez, 2007, page 171).

There was greater tax effort. At a time when there is much discussion of the erosion of income taxation, it is important to stress that the colonial years were a period when income taxation was acquiring greater significance.

\section{Conclusions}

While Europeans were an important part of the tax-paying population, the tax was not confined to white settlers, and this would have become less the case as the percentage of taxpayers increased.

\section{The upper tail of the income distribution}

It was income tax data for European countries that provided the basis for the pioneering investigations of the upper tail of the income distribution by Vilfredo Pareto, and this is the approach with which I begin. More precisely, the findings for East Africa are summarised in Figure 2 in terms of the inverse Pareto coefficient, $B$, calculated from the share of the total income of the top 0.1 per cent that is received by the top 0.05 per cent. $^{6}$ (The inverse Pareto coefficient is equal to $a /(a-1)$, where $a$ is the Pareto coefficient.) The coefficient $B$ has the interpretation that, if the distribution has the Pareto form, then at any income level, $y$, the average income of those with incomes greater or equal to $y$ is equal to By. From Figure 2, it may be seen that, except

\footnotetext{
${ }^{5}$ The figures after 1964 are affected by the introduction of taxation at source (PAYE).

${ }^{6}$ It should be noted that the calculation of $\beta$ does not require an income total; it is based solely on the relative shares.
} 
for the late 1940s/early 1950s in Tanganyika, the coefficient was less than 2 in East Africa, corresponding to a Pareto coefficient in excess of $2 .{ }^{7}$ The latter is a relatively high value, indicating a low level of concentration. In 1951, Colin Clark summarised "all available" Pareto coefficients (1951, pages 533-537). He listed 152 estimates from 23 countries, and only 20 of these exceeded 2 . The highest value recorded by Clark was 2.46 in New Zealand, which corresponds to $B=1.68$.

The Beta coefficients in East Africa around 1950 were of the order of 1.9 (Tanganyika reached 1.94 by 1953); they then proceeded to fall in the 1950s. By 1960 they were closely grouped between 1.51 and 1.56, corresponding to a Pareto coefficient in excess of 2.75. On the eve of independence, the level of concentration was therefore relatively low. The value of Beta may be compared with that in the United Kingdom (UK). The UK Beta coefficient had been close to those in East Africa at the beginning of the 1950s, but it had fallen to a lesser extent over the decade and in 1960 was significantly higher at 1.79 .

In contrast, the 1960s saw a rather different evolution. This is of particular interest, since it was in the early 1960s that the countries gained independence: 1961 in Tanzania, 1962 in Uganda and 1963 in Kenya and Zanzibar. (These years are marked by the vertical lines in Figure 2.) There was no evident continuation of the earlier downward trend in income concentration. The Beta coefficient in Tanzania tended to vary about a stable level; that in Uganda fell and then rose; and that in Kenya fell and then levelled out. By the latter part of the 1960s, there was a clear ranking, with the degree of concentration least in Kenya and greatest in Tanzania, with Uganda in the middle. By this time too the difference from the UK had largely disappeared.

\section{The shape of the distribution}

Summarising the evidence in terms of a single Beta coefficient is justified where the distribution is approximately Pareto in form. How valid is this assumption? The standard way of investigating this issue is to map the cumulative distribution, $\mathrm{F}$, or rather the logarithm of the reverse distribution, $\log _{e}(1-F)$, as a function of the logarithm of the income level, $\log _{e}(y)$, for each of the ranges observed. This approach, however, ignores the information on the total income received by each range. An alternative is to consider the Lorenz curve, which considers the share of total income and the share of total population, but this ignores the information about the income level at which each range commences. In view of this, a different approach is adopted here, which considers the average income above $y$ as a ratio to $y$, the ratio being

\footnotetext{
${ }^{7}$ In the graphs, KE denotes Kenya, TZ Tanzania, UG Uganda and ZZ Zanzibar.
} 
denoted by $M$. In the Pareto case, this is a constant, equal to Beta, so that a simple test of the Pareto assumption is to check how $M$ varies as we consider different points in the distribution.

If we take the case of Zanzibar, shown in Figure 3 , then the $M$ curves are generally falling as $F$ approaches 1 . In 1951, $M$ is close to 3 at the 0.5 percentile, but falls to 1.8 at the 0.1 percentile. The $M$ curves in the case of Zanzibar bear out the conclusion from Figure 2 that the upper tail was becoming less concentrated over the course of the 1950s, since the curves are progressively lower, but hardly provide support for the assumption that the distribution is Pareto in form. A least squares fit to the data for 1958, for example, yields an equation

$$
1.31+90.6(1-\mathrm{F})
$$

where the standard error of the coefficient is given in the bracket. This fitted relationship implies that the predicted value at the 0.5 percentile is 1.79 , compared with 1.40 at the 0.05 percentile. In the same way, in Kenya, the $M$ curves after independence are far from being horizontal lines - see Figure 4. In 1969 the coefficient of (1-F) is 92.5 with a standard error of 3.3. Moreover, the curves do not always slope downwards. For 1964, there is a distinct upturn within the top 0.05 per cent. In this sense, independence changed the shape of the upper tail. As a result, the $M$ curves for 1964 and 1969 (both shown with bold markers in Figure 4) intersect, so that the outcome indicated by a single value of $M$ may be misleading. At the 0.25 percentile, $M$ has increased; at the 0.05 percentile, $M$ has fallen. In the cases (not shown) of Tanganyika and Uganda, there is a pronounced $\mathrm{U}$-shape for the $M$ curves in the preindependence period. In Uganda, in the year before independence (1961), the value of $M$ is around 2 at the 0.25 percentile, falls to 1.44 at the 0.05 percentile and then rises to around 1.6. In Tanzania, in the year before independence (1960), the value of $M$ is around 2 at the 0.35 percentile, falls to 1.55 at the 0.05 percentile and then rises to around 1.7. Again the shape changes after independence, and the M curves for 1962 (1961 in Tanzania) and 1970 intersect, although the intersection is within the top 0.05 per cent.

The position at the end of the 1960 s is summarised in Figure 5 . There is a clear ranking of the three countries, with Kenya being the least concentrated (lower $M$ curve) and Tanzania the most concentrated. This bears out the earlier finding, but Figure 5 also allows a more nuanced conclusion. The top of the distribution differs in shape, with the $M$ curves sloping downwards much more sharply in Tanzania and Uganda than in Kenya. The limiting value of $M$ is indeed close to 1.4 in all three countries.

\section{Conclusions}


The post-war colonial period as a whole saw a distinct fall in the degree of income concentration in British East Africa, as measured by the (inverse) Pareto coefficient, so that at the time of independence, there was less concentration at the top than in the UK. The downward trend in income concentration did not continue in the 1960s after independence. It may not however be enough to summarize the shape of the distribution in a single number, such as the Pareto coefficient. The shape of the upper tail differed across colonies, but in all cases departed from the simple Pareto form.

\section{Putting the data in context: control totals for income}

If the population totals - discussed in Section 3 - pose problems, then control totals for household income take us into still more treacherous territory. The starting point for the control total for total household income is national income. The difficulties in calculating national income in Africa are widely recognised: "the quality of macroeconomic data in Tanzania has for a long time been a problem for researchers ... A particular concern was the poor coverage of the informal sector or the "second economy" (Bigsten and Danielson, 2001, page 29). There is much criticism of contemporary national accounts estimates for Africa. According to Devarajan, for example, Africa today "is facing a statistical tragedy, in that the statistical foundations of the recent growth in per-capita GDP ... are quite weak" (2013, page S9). On the other hand, work on national accounts was pioneered in a number of African colonies at much the same time as official national accounts were coming into use in OECD countries. There are therefore building blocks for the period studied here (up to 1970) that can be used.

\section{Kenya}

As noted by Kennedy, Ord and Walker, "Kenya was one of the first of the colonial territories to have official estimates of domestic income and product as an annual time series" (1963, page 360). The Second Conference of Colonial Statisticians in 1953 reported that official estimates of national income for Kenya were in regular production (Colonial Office, 1954, page 41). The East African Statistical Department first published estimates for the years 1947, 1948 and 1949 in the Quarterly Economic and Statistical Bulletin, December 1950, and these have continued on a regular basis. There have however been substantial revisions. In 1959, a major revision of national accounts in Kenya was carried out, leading to an upward revision of the series from 1954 to 1958 (East African Statistical Department, 1959). A new set of calculations, made incorporating more up-to-date basic data, were made from 1967, with a revised series from 1963. A further major revision was undertaken in 1976, with revised figures backdated to 1972 . 
The income total is based on GDP at factor cost, corresponding to factor incomes, where it is important to note that this includes an estimate of subsistence income from agriculture. In 1951, for example, this accounted for 22 per cent of the total. The total employed here was constructed by linking different series backwards - see Appendix D. It should be noted that the combined effect of the up-rating factors is to raise the earlier estimates by some 60 per cent.

GDP at factor prices does not correspond to total household income. Adjustments have to be made for net factor paid abroad, for depreciation, for retained corporate profits, for non-profit institutions, and for government interest and transfers received by households. The national accounts for the period in question do not allow these adjustments to be made. The estimates of Bigsten show that Net National Income after subtracting the public sector operating surplus was close to 88 per cent of GDP at factor cost over the period 1936 to 1976. In view of this, a figure of 85 per cent of GDP at factor cost is employed here as the income control total.

\section{Tanganyika}

The first national accounts figures for Tanganyika were prepared in 1955 for the Royal Commission on East Africa, and published in their report. These were however described by Kennedy, Ord and Walker as "very inadequate 'back of the envelope' type of estimates (1963, page 358), and the systematic construction of national income series was begun by Peacock and Dosser (1958), who made estimates for 1952-1954. Their work was continued by the East African Statistical Department, published as "The Gross Domestic Product of Tanganyika 1954-57". The next set of estimates, National Accounts of Tanganyika, 1960-62 was published in 1964 based on the 1953 SNA. In 1968 the Bureau of Statistics embarked on a comprehensive revision of the national accounts. The estimates used here are obtained by linking the series backwards - see Appendix D.

In order to allow for the inclusion of Zanzibar for the years from 1966 to 1970, the figures for these years for Tanzania mainland are adjusted upwards by a percentage was based on a comparison of the GDP for the Zanzibar Protectorate for the years 1957 to 1961 (see below) with the mainland totals (East African Common Services Organization, 1963, Table 20). For the years from 1962, the percentage has been interpolated on the basis of the percentage recorded for 1977 when the GDP of Zanzibar was reported in the Statistical Abstract of the United Republic of Tanzania Zanzibar, volume II, 1982, Table P.1. The same interpolated percentage was used to calculate the GDP for Zanzibar for the years 1962 to 1965 used below. 
Total household income is typically less than measured national income, but it is not straightforward to separate out the retained profits of corporations, corporate taxes and factor income received by the government. The United Nations Yearbook of National Accounts Statistics for 1969 included a table for Tanzania showing the "distribution of the national income" (volume 1 , page 694). Over the period from 1960 to 1967, the sum of compensation of employees, income from unincorporated enterprises, property income and corporate transfer payments varied between 79 and 84 per cent of net national product at factor cost. In view of the omission of certain items, such as debt interest paid by the government, I have taken total gross household income as being 85 per cent of GDP at factor prices throughout the period considered.

The assumptions made here about total income can be described as "conservative". Use of the "old" series of Bigsten and Danielson may well mean that GDP is here under-stated. The potential error certainly seems in that direction. As is noted by Bigsten and Danielson, the "new" series introduced by the Bureau of Statistics from 1985 involved a very large upward shift. The 1985 estimate is a "staggering" (their words) 65 per cent higher. Even though the official estimates for the 1950s did incorporate, as explained in the Quarterly Economic and Statistical Bulletin (June 1959, page 67, an increased allowance for the output of the subsistence economy, this may still have been understated. It may be noted that the linking of the series leads to an estimate for 1952 that is some 12 per cent below the estimate of Peacock and Dosser. The key role of the valuation of non-marketed income was stressed in the review of their work by Deane (1959). As she notes, "widely differing estimates of the total could be reached by valuing subsistence output at less than local market prices or by including further processing imputations" (1959, page 576). ${ }^{8}$ The implications of different degrees of possible under-statement are discussed when considering the results.

\section{Uganda}

In December 1952, the East African Statistical Department published preliminary estimates of the national income for Uganda for 1950 and 1951, which were less detailed than those for Kenya (see Kennedy, Ord and Walker, 1963, page 362). The publication The geographical income of Uganda, 1950 to 1956 gave revised estimates covering those years. The income total is based on GDP at factor cost, corresponding to factor incomes, where this includes an estimate of subsistence income from agriculture. In 1952, for example, this accounted for 24 per cent of the total. The total used here is constructed by linking different series backwards - see Appendix D.

\footnotetext{
${ }^{8}$ The arbitrariness is illustrated by Martin in his discussion of the official estimates by reference to the valuation of hut construction: "it is assumed that the number of huts in existence is equal to the number of adults in the population, that a hut lasts ten years and that it costs $\mathrm{f} 10$ to build" (1963, page 340).
} 
GDP at factor prices does not correspond to total household income. Adjustments have to be made for net factor paid abroad, for depreciation, for retained corporate profits, for non-profit institutions, and for government interest and transfers received by households. The national accounts for the period in question do not allow these adjustments to be made. The published estimates for the 1950s do allow one to subtract the profits and surpluses of the Statutory Marketing Boards and of public enterprises. The resulting figures fluctuated considerably, but over the period 1950 to 1958 averaged 88 per cent of total domestic income. In view of this, a figure of 85 per cent of GDP at factor cost is employed here as the income control total.

\section{Zanzibar}

In February 1963, the East African Statistical Department published estimates of the national income for the Zanzibar Protectorate. The Introduction to the report described them as follows:

"The set of accounts put forward here are not the first which have been drawn up by the East African Statistical Department for Zanzibar. They are, however, the first to be published and are considered to be an improvement on previous estimates. Even so, largely because of the limited nature of the statistics available, it is improbable that they are completely accurate and it is likely that when more statistics become available the estimates shown will need revision. Thus these figures are presented merely to provide some indication of the orders of magnitude involved in the economic structure of Zanzibar" (1963, page 1).

These estimates of GDP at factor cost for 1957 to 1961 have been used here, but the caution stated above should be borne in mind. No income totals have been used for years prior to 1957, so that no income share estimates have been made. The totals for 1962 and 1963 have been calculated as a percentage of the mainland Tanzania figure.

GDP at factor prices does not correspond to total household income. Adjustments have to be made for net factor paid abroad, for depreciation, for retained corporate profits, for non-profit institutions, and for government interest and transfers received by households. The national accounts for the period in question do not allow these adjustments to be made. In the light of the experience with other East African countries, a figure of 85 per cent of GDP at factor cost is employed here as the income control total.

\section{Conclusions}


The potential margins of error in the control total should be evident. The assumption of 85 per cent in going from national income to household income is clearly at best an approximation. The successive up-ratings of GDP at different revisions may have been in the correct direction, but the application of the correction factors to earlier years represents a sizeable departure from the published figures.

\section{Top income percentiles and shares}

What can be said, using the income totals, about the shares of top incomes? In 1948, in the United Kingdom the share of the top 0.1 per cent in total income was around 4 per cent, implying that this group on average had some 40 times their proportionate share. With the control totals for income in East Africa, we can estimate the corresponding shares in the colonial territories, to see how they compare with those in the UK. Since the basic data are in the form of grouped tabulations, and the intervals do not in general coincide with the percentage groups of the population with which we are concerned (such as the top 0.1 per cent), we have to interpolate in order to arrive at the shares of total income. In the results presented here, the interpolation is based on the mean-split histogram (see Atkinson, 2005). ${ }^{9} 10$

The share, $\mathrm{S}_{001}$, of the top 0.1 per cent may be seen as governed by (a) the threshold level of income, $y_{001}$, required to be in this group, expressed as a proportion of the mean income, $\mu$, and (b) the degree of concentration within the top 0.1 per cent, which is given by the value of $M, M_{001}$, discussed in Section 5 . The formula is:

Ratio of income share to population share equals

$M$ times the threshold (expressed relative to the mean).

This requires use of the control total for income to calculate the mean income, which in 1948 was $£ 22$ a year in Tanganyika, £33 in Uganda and £35 in Kenya. As has been stressed, the control totals are surrounded by considerable uncertainty, which may affect both the levels and the relative positions of the different countries. It may however be noted that the estimates by Maddison (2003, Table 6c) of GDP per capita, adjusted for purchasing power differences, in 1950 gives very similar figures for Kenya and Uganda, and that the estimate

\footnotetext{
${ }^{9}$ In a few cases (for example, Uganda 1954 to 1956) where the relevant percentile is close to the lower limit of the open top interval, the estimates have been obtained by extrapolation, assuming a Pareto distribution with a coefficient determined by the cumulative distribution for the top two intervals.

${ }^{10}$ The method cannot be applied in the case of percentiles, since the argument involving meanpreserving transfers does not apply (see Atkinson, 2005). The percentiles have been calculated by Pareto interpolation applied to each interval using the cumulative distribution.
} 
for Tanganyika is 65 per cent of that for Kenya, which is very close to that implied by the mean incomes used here (63 per cent).

In the UK at the end of the 1940s, $M$ was around 2, and the threshold for the top 0.1 per cent was around 20, generating the multiple of 40 cited above. We have seen that the East African countries had rather similar values at the time. What about the threshold? The threshold for the top 0.1 per cent is shown in Figure 6. In Kenya and Tanganyika (but not Uganda), it was much higher than in the UK: around 35. The same applies to the threshold for the top 0.05 per cent (not shown), where the UK threshold in 1949 was around 27, whereas those in Kenya (47) and Tanzania (50) were approaching more than double. As stressed earlier, there is considerable uncertainty surrounding the income control totals, and hence about mean income, but it seems improbable that the error was such that average incomes in East Africa were understated by 100 per cent or more.

Taken together, these two elements mean that the top income shares in Kenya and Tanganyika at the end of the 1940s were much higher than in the UK - see Figure 7 and Table 1 . The top 0.1 per cent in 1948 had on average 64 times (Kenya) and 74 times (Tanganyika) their proportionate share. In Uganda, in contrast, the threshold ratio, at 36, was similar to that in the UK. The share of the top 0.01, an even smaller group, was also similar in Uganda to that in the UK (1.1 per cent, or 110 times the proportionate share).

\section{Changes over time}

How did the percentiles and shares change over time? From Figure 6, we can see that over the post-war colonial years the threshold required to enter the top 0.1 per cent was either stable (Kenya), rising moderately (Tanganyika) or rising substantially (Uganda). Combined with the reduced concentration identified in Section 5, this implied that the share of the top 0.1 per cent in Kenya at the time of independence was 1 percentage point lower than it had been in 1948 - see Figure 7. This still meant that it was higher than the corresponding share in the UK, which had fallen substantially over the intervening period. This was even more the case in Tanganyika: at independence in 1961, the top 0.1 per cent had 66 times their proportionate share, whereas the UK share was some 25 times. In Uganda, the rise in the threshold brought the top income shares closer to those in the other East African countries. The series for Zanzibar is shorter, but the income shares were close to those in Uganda. At the time of independence, there was in fact relatively little difference between the four countries: the share of the top 0.1 per cent was around 5 per cent in Uganda and Zanzibar, and 61/2 per cent in Tanzania, with Kenya in-between. (The ranking of Kenya and Uganda differs from that in Section 5 in terms of the $M$ ratio, since the difference in the threshold more than offsets the difference in the opposite direction for $\mathrm{M}_{\text {.) }}$ 
These top shares are well above those in the UK at that time. Even if the control total in Kenya were doubled, the share would still be above that in the UK in 1960.

What happened after independence? We saw earlier (Figure 2) that the decline in concentration that had taken place in the colonial period came to an end after independence. On the other hand, the threshold fell, particularly in Tanzania and Uganda. As a result, the top income shares fell - see Figure 7. At the end of the 1960s, the share of the top 0.1 per cent was around 4 per cent in Uganda and 5 per cent in Kenya and Tanzania. The share of the top 0.05 per cent was around $2 \frac{1}{2}$ per cent in Uganda and 3 per cent in Kenya and Tanzania (Table 1). Finally, we may note that the income tax data suggest that top shares are larger than observed in household surveys. Huang found for Tanzania using the 1969 Household Budget Survey that the top 0.4 per cent of households received 9.2 per cent of total household income (1976, Table 1). In 1964, the income tax data show a share of 9.1 per cent for a considerably smaller group: the top 0.25 per cent.

\section{Conclusions}

The estimates presented here must be qualified in the light of the limitations set out in the paper, but they are sufficient to demonstrate the potential of the income tax data and to show how the historical experience has to be interpreted in nuanced manner. No one single statistic can adequately summarise the changes over time or the differences between countries.

In summary, the findings indicate that during the colonial period the top of the distribution became less concentrated, particularly in the first half of the 1950s, but that the threshold to enter the top income groups increased relative to mean income. As a result, the shares in total income of top groups fell in Tanzania, were broadly stable in Kenya and rose in Uganda. After independence, concentration was broadly unchanged, but the thresholds fell, leading to a decline in top income shares. The changes up to the end of the 1960 s were not however dramatic.

At independence, the degree of concentration was similar across the four countries, with a Pareto coefficient in excess of 2.75 , which implies a relatively low level of concentration by international standards (and by comparison with the UK at that time). The threshold to enter the top groups, and hence the top share, was lower in Uganda (and Zanzibar). The threshold was highest in Tanzania, and correspondingly the top shares were larger. Even 
allowing for possible under-statement of total income, the top shares were greater in East Africa than in the UK at the time.

The results presented here end in 1970. It is hoped that this historical picture will be followed by the publication of tabulations for the period since then. 


\section{Appendix A: Sources of income tax data}

Years shown in italics are not used in the analysis.

Table A1 Income tax and income tax data in Kenya

\begin{tabular}{|c|c|c|c|}
\hline $\begin{array}{l}\text { Income } \\
\text { year }\end{array}$ & Source of data & $\begin{array}{l}\text { Definition } \\
\text { of income }\end{array}$ & Notes \\
\hline & $\begin{array}{l}\mathrm{AR}=\text { East African Income Tax } \\
\text { Department Annual Report }\end{array}$ & & \\
\hline 1936 & $\begin{array}{l}\text { Report of the Taxation Enquiry } \\
\text { Committee Kenya 1947, Appendix } 0\end{array}$ & Actual & $\begin{array}{l}\text { Classified by "Europeans" } \\
\text { and "Asians and others" }\end{array}$ \\
\hline 1943 & $\begin{array}{l}\text { Report of the Taxation Enquiry } \\
\text { Committee Kenya 1947, Appendix } 0\end{array}$ & Actual & Ditto \\
\hline 1948 & AR 1952, Schedule 5 & Actual & Ditto \\
\hline 1949 & AR 1953, Schedule 5 & Actual & Ditto \\
\hline 1950 & AR 1954, Schedule 5 & Actual & \\
\hline 1951 & AR 1954, Schedule 5 & Actual & \\
\hline 1952 & AR 1954, Schedule 5 & Actual & \\
\hline 1953 & AR 1955-56, Schedule 5 & Actual & \\
\hline 1954 & AR 1956-57, Schedule 5 & Actual & \\
\hline 1955 & AR 1957-58, Schedule 5 & Actual & \\
\hline 1956 & AR 1957-58, Schedule 5 & Actual & \\
\hline 1957 & AR 1958-59, Schedule 5 & Actual & \\
\hline 1958 & AR 1959-60, Schedule 5 & Actual & \\
\hline 1959 & AR 1960-61, Schedule 5 & Actual & \\
\hline 1960 & AR 1961-62, Schedule 5 & Actual & \\
\hline 1961 & AR $1962-63$, Schedule 5 & Actual & \\
\hline 1962 & AR 1963-64, Schedule 5 & Actual & \\
\hline 1963 & AR $1964-65$, Schedule 5 & Actual & \\
\hline 1964 & AR $1965-66$, Schedule 5 & Actual & \\
\hline 1965 & AR 1966-67, Schedule 5 & Actual & $\begin{array}{l}\text { Affected by introduction of } \\
\text { PAYE for basic rate of tax. }\end{array}$ \\
\hline 1966 & AR 1967-68, Schedule 5 & Actual & Ditto \\
\hline 1967 & AR $1968-69$, Schedule 5 & Actual & Ditto \\
\hline 1968 & AR 1969-70, Schedule 5 & Actual & Ditto \\
\hline 1969 & AR 1970-71, Schedule 5 & Actual & Ditto \\
\hline \multirow{2}{*}{1970} & AR 1971-72, Schedule 5 & Actual & Ditto \\
\hline & & & $\begin{array}{l}\text { From this point affected by } \\
\text { the introduction of PAYE } \\
\text { for all rates of tax on } \\
\text { employment income. }\end{array}$ \\
\hline 1973 & $\begin{array}{l}\text { Income Tax Statistics report Year of } \\
\text { Income 1973, Ministry of Planning } \\
\text { and Community Affairs }\end{array}$ & $\begin{array}{l}\text { Actual in } \\
\text { Schedule 5; } \\
\text { chargeable in } \\
\text { Schedule } 6 .\end{array}$ & \\
\hline 1974 & $\begin{array}{l}\text { Income Tax Statistics report Year } \\
\text { of Income 1974, Ministry of } \\
\text { Planning and Community Affairs, } \\
\text { Schedule } 5\end{array}$ & Actual & \\
\hline 1975 & Income Tax Statistics report Year & Actual & \\
\hline
\end{tabular}




\begin{tabular}{|l|l|l|l|}
\hline & $\begin{array}{l}\text { of Income 1975, Ministry of } \\
\text { Planning and Community Affairs, } \\
\text { Schedule 5 }\end{array}$ & & \\
\hline 1976 & Statistical Abstract 1982, page 214 & Chargeable & \\
\hline 1977 & $\begin{array}{l}\text { Income Tax Statistics Report for } \\
\text { Years of Income 1977 and 1978, } \\
\text { Ministry of Planning and National } \\
\text { Development, Feb 1987, Schedule 5 }\end{array}$ & Actual & $\begin{array}{l}\text { Chargeable income in } \\
\text { Statistical Abstract 1984, } \\
\text { page 205. }\end{array}$ \\
\hline 1978 & $\begin{array}{l}\text { Income Tax Statistics Report for } \\
\text { Years of Income 1977 and 1978, } \\
\text { Ministry of Planning and National } \\
\text { Development, Feb 1987,Sch 5 }\end{array}$ & Actual & $\begin{array}{l}\text { Chargeable income in } \\
\text { Statistical Abstract, 1986, } \\
\text { page 202. }\end{array}$ \\
\hline 1979 & Statistical Abstract, 1988, page 206 & Chargeable & \\
\hline 1980 & Statistical Abstract, 1989, page 207 & Chargeable & \\
\hline
\end{tabular}

Table A2 Income tax and income tax data in Tanganyika/Tanzania

\begin{tabular}{|c|c|c|c|}
\hline $\begin{array}{l}\text { Income } \\
\text { year }\end{array}$ & Source of data & $\begin{array}{l}\text { Definition } \\
\text { of income }\end{array}$ & Notes \\
\hline & $\begin{array}{l}\text { AR = East African Income Tax } \\
\text { Department Annual Report }\end{array}$ & & \\
\hline 1948 & AR 1952, Schedule 5 & Actual & $\begin{array}{l}\text { Classified by "Europeans" } \\
\text { and "Asians and others }\end{array}$ \\
\hline 1949 & AR 1953, Schedule 5 & Actual & $\begin{array}{l}\text { Classified by "Europeans" } \\
\text { and "Asians and others }\end{array}$ \\
\hline 1950 & AR 1954, Schedule 5 & Actual & \\
\hline 1951 & AR 1954, Schedule 5 & Actual & \\
\hline 1952 & AR 1954, Schedule 5 & Actual & \\
\hline 1953 & AR $1955-56$, Schedule 5 & Actual & \\
\hline 1954 & AR 1956-57, Schedule 5 & Actual & \\
\hline 1955 & AR $1957-58$, Schedule 5 & Actual & \\
\hline 1956 & AR $1957-58$, Schedule 5 & Actual & \\
\hline 1957 & AR $1958-59$, Schedule 5 & Actual & \\
\hline 1958 & AR $1959-60$, Schedule 5 & Actual & \\
\hline 1959 & AR $1960-61$, Schedule 5 & Actual & \\
\hline 1960 & AR 1961-62, Schedule 5 & Actual & \\
\hline 1961 & AR $1962-63$, Schedule 5 & Actual & \\
\hline 1962 & AR 1963-64, Schedule 5 & Actual & \\
\hline 1963 & AR 1964-65, Schedule 5 & Actual & \\
\hline 1964 & AR 1965-66, Schedule 5 & Actual & \\
\hline 1965 & AR 1966-67, Schedule 5 & Actual & $\begin{array}{l}\text { Affected by introduction of } \\
\text { PAYE for basic rate of tax. }\end{array}$ \\
\hline 1966 & AR 1967-68, Schedule 5 & Actual & $\begin{array}{l}\text { Ditto. Includes Zanzibar } \\
\text { from this point. }\end{array}$ \\
\hline 1967 & AR 1968-69, Schedule 5 & Actual & Ditto \\
\hline 1968 & AR $1969-70$, Schedule 5 & Actual & Ditto \\
\hline 1969 & AR $1970-71$, Schedule 5 & Actual & Ditto \\
\hline 1970 & AR 1971-72, Schedule 5 & Actual & Ditto \\
\hline 1973 & Break-up of East Africa Income Tax & & \\
\hline
\end{tabular}




\begin{tabular}{|l|l|l|l|}
\hline & Department & & \\
\hline 1974 & $\begin{array}{l}\text { Income Tax Statistics Year of } \\
\text { Income 1974, Table 6 }\end{array}$ & Actual & $\begin{array}{l}\text { First year for which data } \\
\text { prepared by Bureau of } \\
\text { Statistics, Tanzania. } \\
\text { Comparability not clear. }\end{array}$ \\
\hline
\end{tabular}

Table A3 Income tax and income tax data in Uganda

\begin{tabular}{|l|l|l|l|}
\hline $\begin{array}{l}\text { Income } \\
\text { year }\end{array}$ & Source of data & $\begin{array}{l}\text { Definition } \\
\text { of income }\end{array}$ & Notes \\
\hline 1948 & $\begin{array}{l}\text { AR }=\text { East African Income Tax } \\
\text { Department Annual Report }\end{array}$ & & \\
\hline 1949 & AR 1952, Schedule 5 & Actual & $\begin{array}{l}\text { Classified by “Europeans" } \\
\text { and “Asians and others }\end{array}$ \\
\hline 1950 & AR 1953, Schedule 5 1954, Schedule 5 & Actual & $\begin{array}{l}\text { Classified by “Europeans" } \\
\text { and “Asians and others }\end{array}$ \\
\hline 1951 & AR 1954, Schedule 5 & Actual & \\
\hline 1952 & AR 1954, Schedule 5 & Actual & \\
\hline 1953 & AR 1955-56, Schedule 5 & Actual & \\
\hline 1954 & AR 1956-57, Schedule 5 & Actual & \\
\hline 1955 & AR 1957-58, Schedule 5 & Actual & \\
\hline 1956 & AR 1957-58, Schedule 5 & Actual & \\
\hline 1957 & AR 1958-59, Schedule 5 & Actual & \\
\hline 1958 & AR 1959-60, Schedule 5 & Actual & \\
\hline 1959 & AR 1960-61, Schedule 5 & Actual & \\
\hline 1960 & AR 1961-62, Schedule 5 & Actual & \\
\hline 1961 & AR 1962-63, Schedule 5 & Actual & \\
\hline 1962 & AR 1963-64, Schedule 5 & Actual & \\
\hline 1963 & AR 1964-65, Schedule 5 & Actual & \\
\hline 1964 & AR 1965-66, Schedule 5 & Actual & \\
\hline 1965 & AR 1966-67, Schedule 5 & Actual & \\
\hline 1966 & AR 1967-68, Schedule 5 & Actual & Affected by introduction of \\
& PAYE for basic rate of tax. \\
\hline 1967 & AR 1968-69, Schedule 5 & Actual & Ditto \\
\hline 1968 & AR 1969-70, Schedule 5 $1970-71$, Schedule 5 & Actual & Ditto \\
\hline 1969 & AR 1971-72, Schedule 5 & Actual & Ditto \\
\hline 1970 & Actual & Ditto \\
\hline
\end{tabular}

Table A4 Income tax and income tax data in Zanzibar

\begin{tabular}{|l|l|l|l|}
\hline $\begin{array}{l}\text { Income } \\
\text { year }\end{array}$ & Source of data & $\begin{array}{l}\text { Definition } \\
\text { of income }\end{array}$ & Notes \\
\hline & $\begin{array}{l}\text { AR = East African Income Tax } \\
\text { Department Annual Report }\end{array}$ & & \\
\hline
\end{tabular}




\begin{tabular}{|c|c|c|c|}
\hline 1948 & AR 1952, Schedule 5 & Actual & $\begin{array}{l}\text { Classified by "Europeans" } \\
\text { and "Asians and others }\end{array}$ \\
\hline 1949 & AR 1953, Schedule 5 & Actual & $\begin{array}{l}\text { Classified by "Europeans" } \\
\text { and "Asians and others }\end{array}$ \\
\hline 1950 & AR 1954, Schedule 5 & Actual & \\
\hline 1951 & AR 1954, Schedule 5 & Actual & \\
\hline 1952 & AR 1954, Schedule 5 & Actual & \\
\hline 1953 & AR 1955-56, Schedule 5 & Actual & \\
\hline 1954 & AR 1956-57, Schedule 5 & Actual & \\
\hline 1955 & AR 1957-58, Schedule 5 & Actual & \\
\hline 1956 & AR 1957-58, Schedule 5 & Actual & \\
\hline 1957 & AR 1958-59, Schedule 5 & Actual & \\
\hline 1958 & AR 1959-60, Schedule 5 & Actual & \\
\hline 1959 & AR 1960-61, Schedule 5 & Actual & \\
\hline 1960 & AR 1961-62, Schedule 5 & Actual & \\
\hline 1961 & AR 1962-63, Schedule 5 & Actual & \\
\hline 1962 & AR 1963-64, Schedule 5 & Actual & \\
\hline 1963 & AR 1964-65, Schedule 5 & Actual & \\
\hline 1964 & AR 1965-66, Schedule 5 & Actual & $\begin{array}{l}\text { The data do not appear to } \\
\text { be comparable: the } \\
\text { numbers and amounts are } \\
\text { approximately half those } \\
\text { in previous year. }\end{array}$ \\
\hline 1965 & AR 1966-67, Schedule 5 & Actual & $\begin{array}{l}\text { Affected by introduction } \\
\text { of PAYE for basic rate of } \\
\text { tax. }\end{array}$ \\
\hline
\end{tabular}




\section{Appendix B: Implications of the introduction of PAYE}

A major change in the administration of the personal income tax came with the introduction of a PAYE system of deduction of tax at source from employment income with effect from $1^{\text {st }}$ July 1966 (see AR 1965-66, Note after para 7). It applied to income tax which was chargeable at the rate of $12 \frac{1}{2}$ per cent on all chargeable income. The additional surtax, chargeable at a graduated scale on chargeable income in excess of $£ 1,000$, continued to be assessed and payable after the end of the year. The tabulations used here continued therefore to provide information about the distribution of incomes at higher levels. By comparing the distributions before and after the change, it appears that ranges above $£ 2,000$ a year were little affected. The estimates given below for 1965 to 1970 therefore only make use of data from £2,000 upwards.

In Kenya, with effect from $1^{\text {st }}$ January 1971, the PAYE system was extended to cover the higher rates of tax, so that higher incomes are not included in the tabulations where tax was collected entirely by PAYE (AR 197172, para 1). As a result, the Income tax statistics report for the year of income 1974 states that "except where PAYE taxpayers are included in the Assessments cases the statistics presented in this report refer exclusively to Income Tax secured from Assessments. This is obviously a serious limitation in the income tax data since the majority of the taxpayers in Kenya fall under the PAYE system" (page 1). In the later Income tax statistics report for years of income 1977 and 1978, there is reference to information on PAYE being collected for the first time in IY1980, allowing "a more subtle and complete analysis of Kenya's income tax structure" (1987, page 2). The figures for IY1980 published in the 1989 Statistical Abstract (page 207) do not however suggest that there have been substantial additions. The estimates here therefore stop in 1970.

The same applies to Tanzania and Uganda, where the estimates also stop in 1970. In the case of Tanzania, data for 1974 were published by the Bureau of Statistics of Tanzania, rather than by the East African Income Tax Department, but the Bureau notes that "there are no comparable data for the previous years" (page 1). 


\section{Appendix C: Control totals for tax units and income}

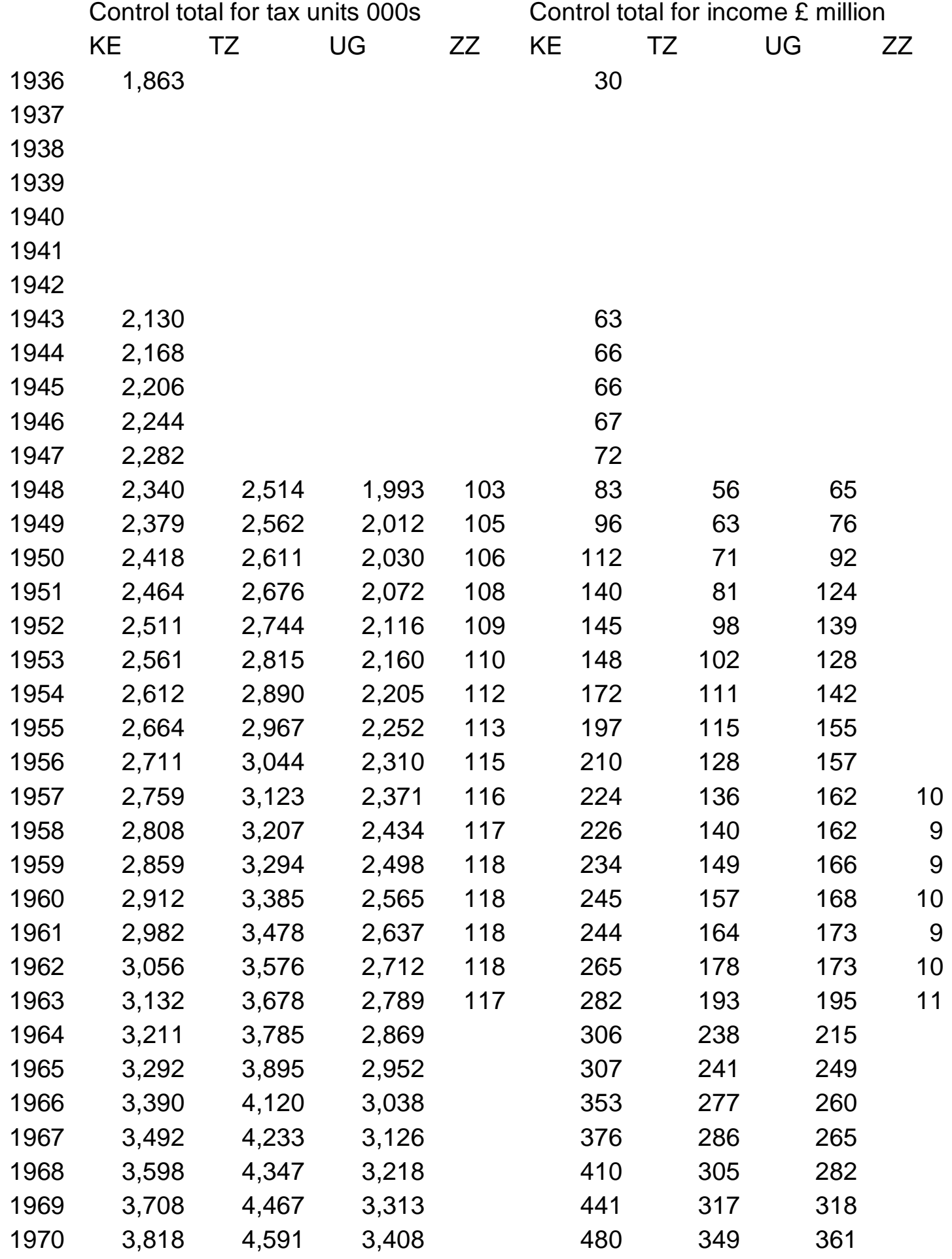

Sources: see text. 


\section{Appendix D: Sources for income control totals}

Kenya

The income total is based on GDP at factor cost, corresponding to factor incomes, where it is important to note that this includes an estimate of subsistence income from agriculture. In 1951, for example, this accounted for 22 per cent of the total. The total employed here was constructed by linking different series backwards, starting from the estimates for 1978 to 1980 In the Statistical Abstract (SA) 1986, page 34, which continued SA 1983, page 34 for 1974 to 1977, and SA 1982, page 34 for 1973. There is a link at 1973 to the earlier series (which involves up-rating the earlier estimates by a factor of 1.089); this series is from SA 1976, page 47, for 1968 to 1973, from SA 1973, page 43, for 1964 and 1966 to 1967, SA 1968, page 33, for 1963 and 1965. There is a link at 1963 to the earlier series (which involves an up-rating by a factor of 1.175); the earlier series is taken from SA 1967, page 30, for 1957 to 1963, from SA 1961, page 110, for 1955 and 1956, from SA 1960, page 105, for 1954 and 1955. At 1954 there is a link to the first official series (involving an up-rating by a factor of 1.248); the series is from the Quarterly Economic and Statistical Bulletin, March 1957, page 95, for 1951 to 1954, from SA 1955, page 89 , for 1947-1950. It should be noted that the combined effect of the up-rating factors is to raise the earlier estimates by some 60 per cent.

There are no official estimates covering years prior to 1947. Use has been made of the estimates of GDP at factor prices by Bigsten (1986, page 147) for 1936 and for 1946 (the years 1943 to 1945 being obtained by applying the ratio of the price index to that in 1946) ${ }^{11}$. The estimates of Bigsten have been linked by applying the ratio of our 1950 estimate to that he made for the same year.

\section{Tanzania}

The systematic construction of national income series was begun by Peacock and Dosser (1958), who made estimates for 1952-1954. Their work was continued by the East African Statistical Department, published as "The Gross Domestic Product of Tanganyika 1954-57". The next set of estimates, National Accounts of Tanganyika, 1960-62 was published in 1964 based on the 1953 SNA. In 1968 the Bureau of Statistics embarked on a comprehensive revision of the national accounts, published successively in the National Accounts of Tanzania 1966-1968, 1964-1972, 1966-1972, 1966-1974, 1966-1976, 1966-1980 and 19701982.

\footnotetext{
${ }^{11}$ The Nairobi retail price index is from the Report of the taxation enquiry committee, Kenya, 1947, Appendix F.
} 
In order to anchor the GDP series, I start from the GDP at current factor cost prices given as the "Old series", covering the years from 1960 to 1970, by Bigsten and Danielson (2001, Table A1) for Tanzania mainland. This series draws on the Bureau of Statistics estimates: for example, the figures for 1964 to 1970 are identical to those in the National Accounts of Tanzania 1964-1972 (Summary Table I) and those for 1970 to 1974 are identical with those National Accounts of Tanzania 1966-1976 (Summary Table I). The series is then linked backwards from 1960 to 1952 using the official estimates given in the East African Economic and Statistical Review (September 1962, page 113, and December 1964, page 105), the Quarterly Economic and Statistical Bulletin (June 1958, page 83), and the 1952-1954 estimates of Peacock and Dosser.

There are no national income estimates for 1948-1951. Approximate figures have been constructed by back-casting the 1952 estimate using an index based half on the cost of living index for Dar-es-salaam (December figure, 1949 interpolated) and half on Central Government revenue (sources: Colonial Office, 1952, pages 66 and 70). The resulting figures for the 1940s are considerably below that for 1952, but this reflects the fact the boom in sisal production (more than half of exports) in the early 1950 s. $^{12}$

\section{Uganda}

The income total is constructed by linking different series backwards, starting from the estimates for 1963 to 1970 In the Statistical Abstract (SA) 1971, pages 92-93. These are linked at 1963 to the series given in the UN Yearbook of National Accounts for 1969, page 730 (which involves up-rating the earlier estimates by a factor of 1.30); this series is continued backwards from 1961 to 1954 in Economic Development of Uganda (World Bank, 1962), page 441. The series is linked backwards at 1954 to that given for total geographical income from 1950 to 1954 in SA 1957, page 79 (which involves an up-rating by a factor of 1.18). It should be noted that the combined effect of the up-rating factors is to raise the earlier estimates by some 50 per cent. There are no national income estimates covering years prior to 1950. Approximate figures for 1948 and 1949 have been constructed by back-casting the 1950 estimate using an index based half on the cost of living index for Kampala (interpolated) and half on Government revenue (sources: Colonial Office, 1952, pages 98 and 102). The resulting figures for the late 1940 s are considerably below that for 1950 , but this reflects in part the increased prices for cotton (supplying nearly half of exports) and coffee. ${ }^{13}$

\footnotetext{
${ }^{12}$ The monthly net value of exports was $£ 4$ million in 1952 , compared with $£ 1.35$ million in 1948 and E2.08 million in 1950 (Digest of Colonial Statistics, November-December 1953, page 6).

${ }_{13}$ The monthly net value of exports was $£ 2.41$ million in 1950 , compared with $£ 1.16$ million in 1948 (Digest of Colonial Statistics, November-December 1953, page 6).
} 


\section{Bibliography}

Atkinson, A B, 2005, "Top incomes in the UK over the twentieth century", Journal of the Royal Statistical Society, vol 168: 325-343.

Bigsten, A, 1986, "Welfare and economic growth in Kenya, 1914-76", World Development, vol 14: 1151-1160.

Bigsten, A, 1986a, Income distribution and growth in a dual economy: Kenya 1914-1976, Department of Economics, Gothenburg University.

Bigsten, A and Danielson, A, 2001, "Tanzania: Is the ugly duckling finally growing up?", Research Report 120, Nordiska Afrikainstitutet, Uppsala University.

Bondestam, L, 1973, "Some notes on African statistics", Research Report no 18, Scandinavian Institute of African Studies, Uppsala University.

Clark, C, 1953, The conditions of economic progress, second edition, Macmillan, London.

Colonial Office, 1952-55, An economic survey of the colonial territories, HMSO, London.

Colonial Office, 1954, Report of the second conference of Colonial Government Statisticians, 1953, Colonial No. 301, HMSO, London.

Deane, P, 1948, The measurement of colonial national incomes: An experiment, Cambridge University Press, Cambridge.

Deane, P, 1959, "Review of the National Income of Tanganyika, 1952-54", Economic Journal, vol 69: 575-576.

Devarajan, S, 2013, "Africa's statistical tragedy", Review of Income and Wealth, series 59: S9-S15.

Due, J F, 1963, Taxation and economic development in tropical Africa, MIT Press, Cambridge, Mass.

East African Common Services Organization, 1963, The Gross Domestic Product of the Protectorate of Zanzibar 1957-1961, East African Statistical Department, Nairobi.

East African Statistical Department, 1950, "Estimates of the geographical net income and output for the years 1947, 1948 and 1949, Colony and Protectorate of Kenya", Nairobi. 
East African Statistical Department, 1959, Domestic income and product in Kenya: A description of sources and methods with revised calculations from 1954-1958, Nairobi.

Gastwirth, J L, 1972, "The estimation of the Lorenz curve and Gini index", Review of Economics and Statistics, vol 54: 306-316.

Green, R H, 1974, "Tanzania” in H Chenery, M S Ahluwalia, C L G Bell, J H Duloy and R Jolly, Redistribution with growth, Oxford University Press, London, pages 268-273.

Hammond, R C, 1975, Fiscal harmonization in the East African Community, International Bureau of Fiscal Documentation, Amsterdam.

Hailey, Lord, 1957, An African survey, 1956 revised edition, Oxford University Press, London.

Hazlewood, A, 1979, The economy of Kenya, Oxford University Press, Oxford. Huang, Y, 1976, "Distribution of the tax burden in Tanzania", Economic Journal, vol 86: 73-86.

ILO, 1972, Employment, income and equality: A strategy for increasing productive employment in Kenya, ILO, Geneva.

Kennedy, T A, Ord, H W and Walker, D, 1963, "On the calculation and interpretation of national accounting material in East Africa" in L H Samuels, editor, African studies in income and wealth, Bowes and Bowes, London: 350432.

Kuczynski, R R , 1949, Demographic survey of the British colonial empire, volume II, Cambridge University Press, London.

Kuznets, S, 1963, "Quantitative aspects of the economic growth of nations: VIII. Distribution of income by size", Economic Development and Cultural Change, vol 11, No. 2, Part 2: 1-80.

Lury, D A, 1966, "Population data in East Africa”, Institute for Development Studies, University College, Nairobi, Discussion paper 18.

Maddison, A, 2003, The world economy: Historical statistics, OECD, Paris.

Martin, C J, 1963, "The development and diversity of national income series in East Africa since 1947" in L H Samuels, editor, African studies in income and wealth, Bowes and Bowes, London: 333-349. 
Mitchell, B R, 1982, International Historical Statistics: Africa and Asia, New York University Press, New York.

Mwega, F M and Ndung'u, N S, 2008, "Explaining African economic growth performance: the case of Kenya" in B J Ndulu, S A O'Connell, J-P Azam, R H Bates, A K Fosu, J W Gunning and D Njinkeu, editors, The political economy of economic growth in Africa, 1960-2000, Cambridge University Press, Cambridge.

Ng'ethe, N, 1980, "Income distribution in Kenya: The politics of mystification", in J F Rweyemamu, editor, Industrialization and income distribution in Africa, Codesria Book Series, Dakar.

Okigbo, P, 1968, "The distribution of national income in African countries" in J Marchal and B Ducros, editors, The Distribution of National Income, Macmillan, London.

Peacock, A T and Dosser, D G M, 1958, The National Income of Tanganyika, 1952-54, Colonial Research Studies No 26, HMSO, London.

Phillips, A 0, 1975, "Review of income distribution data: Ghana, Kenya, Tanzania and Nigeria", Research Program in Economic Development, Discussion Paper 58, Princeton University.

Report of the Commission appointed to enquire into and report on the financial position and system of taxation of Kenya, 1936, HMSO, London.

Samuels, L H, editor, 1963, African Studies in Income and Wealth, Bowes and Bowes, Cambridge.

Thian, P, 1967, A guide to Kenya, Uganda and Tanganyika income tax, Nairobi.

Vallibhoy, F H, 1965, Tax enquiry report 1964/65, Uganda Government Ministry of Finance, Government Printer, Entebbe.

Westlake, M, 1971, "Kenya's extraneous and irrational system of personal income taxation", Institute for Development Studies Staff Paper No 101, Nairobi. 
Table 1 Ethnic composition of East African resident taxpayers assessed in income year 1949

\begin{tabular}{|c|c|c|c|c|c|c|c|}
\hline & TOTAL & Individuals & & & Employees & & \\
\hline & Number & Number & $\%$ total & $\begin{array}{l}\text { Income as } \\
\% \text { total }\end{array}$ & Number & $\%$ total & $\begin{array}{l}\text { Income as } \\
\% \text { total }\end{array}$ \\
\hline \multicolumn{8}{|l|}{ KENYA } \\
\hline Europeans & 12,056 & 1,793 & 44.8 & 52.6 & 10,263 & 82.4 & 86.7 \\
\hline $\begin{array}{l}\text { Asians and } \\
\text { others }\end{array}$ & 4,410 & 2,213 & 55.2 & 47.4 & 2,197 & 17.6 & 13.3 \\
\hline \multicolumn{8}{|c|}{ TANGANYIKA } \\
\hline Europeans & 5,037 & 365 & 26.8 & 41.2 & 4.672 & 85.6 & 87.6 \\
\hline $\begin{array}{l}\text { Asians and } \\
\text { others }\end{array}$ & 1,787 & 998 & 73.2 & 58.8 & 789 & 14.4 & 12.4 \\
\hline & & & & & & & \\
\hline \multicolumn{8}{|l|}{ UGANDA } \\
\hline Europeans & 1,677 & 67 & 8.2 & 12.2 & 1,610 & 62.8 & 62.0 \\
\hline $\begin{array}{l}\text { Asians and } \\
\text { others }\end{array}$ & 1,705 & 752 & 91.8 & 87.8 & 953 & 37.2 & 38.0 \\
\hline & & & & & & & \\
\hline \multicolumn{8}{|l|}{ ZANZIBAR } \\
\hline Europeans & 147 & 6 & 3.2 & 2.9 & 141 & 61.6 & 63.7 \\
\hline $\begin{array}{l}\text { Asians and } \\
\text { others }\end{array}$ & 268 & 180 & 96.8 & 97.1 & 88 & 38.4 & 36.3 \\
\hline & & & & & & & \\
\hline
\end{tabular}

Source: East African Income Tax Department Annual Report 1953, Appendix A. 


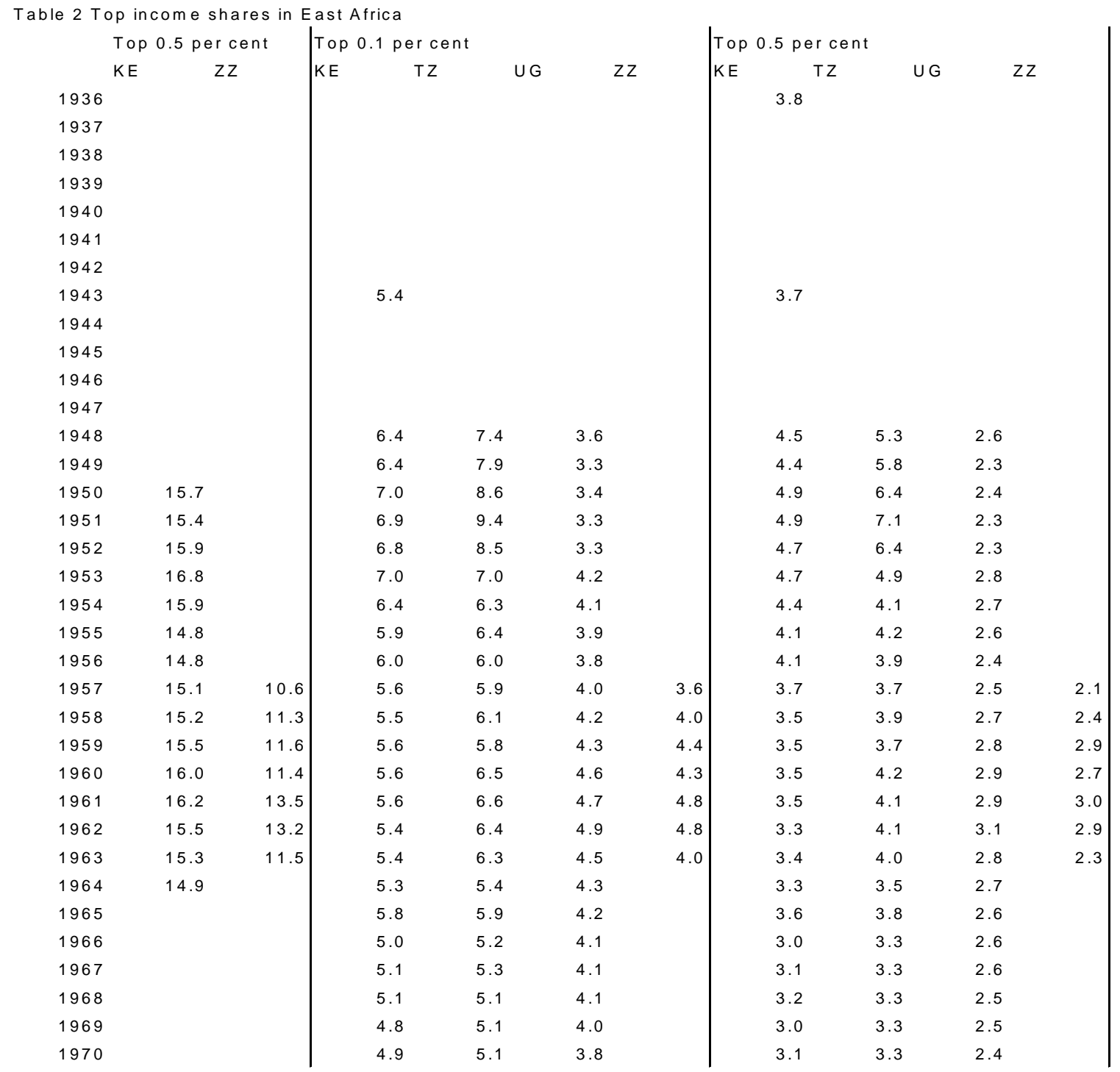

Source: calculated from the income tax sources listed in Appendix A and control totals in Appendix C. 
Figure 1 Income taxpayers in East Africa as \% total tax units

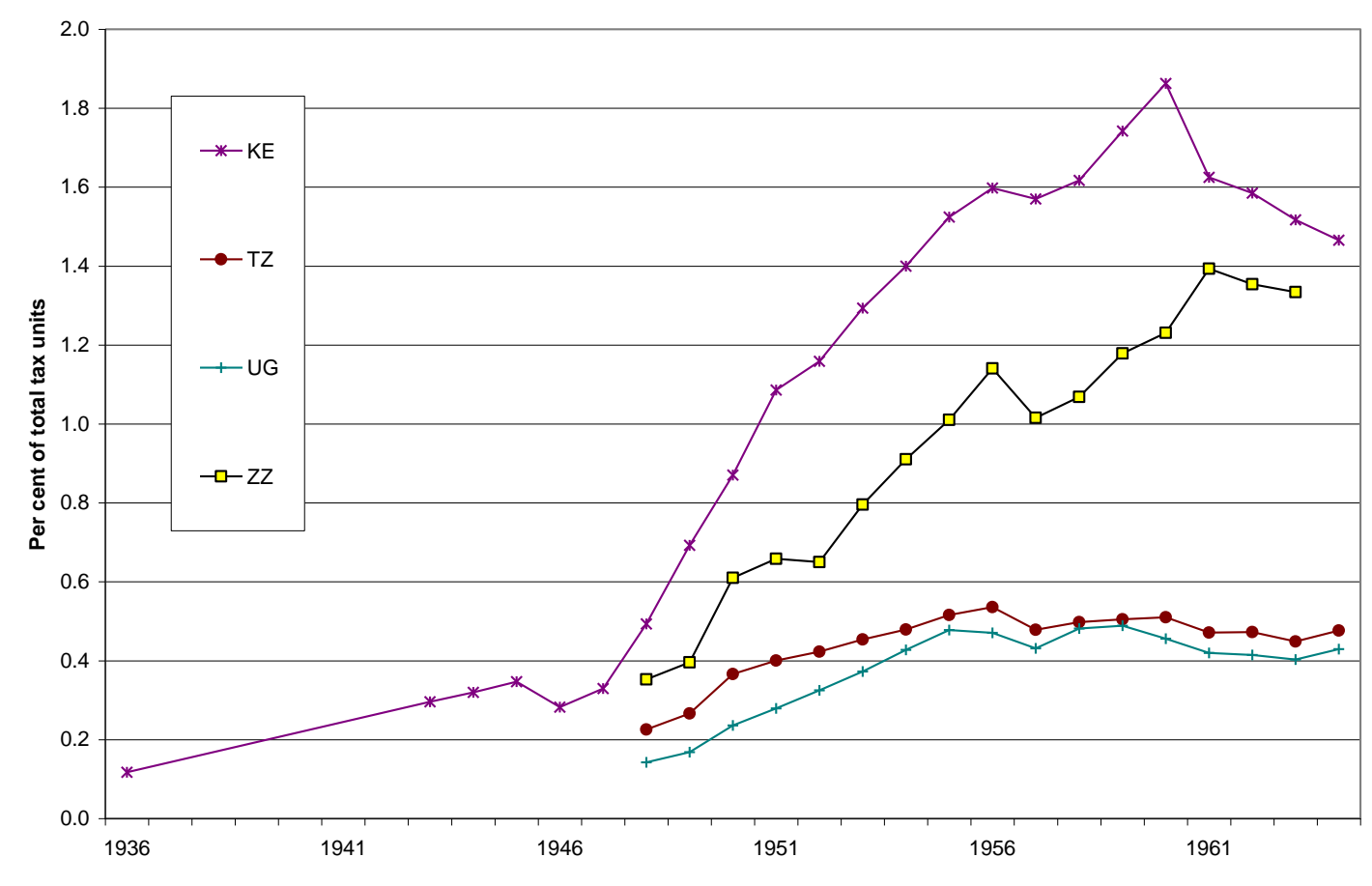

Source: calculated from the income tax sources listed in Appendix A and control totals in Appendix C. 
Figure 2 Pareto (Beta) coefficients for East Africa and the UK (dashed line)

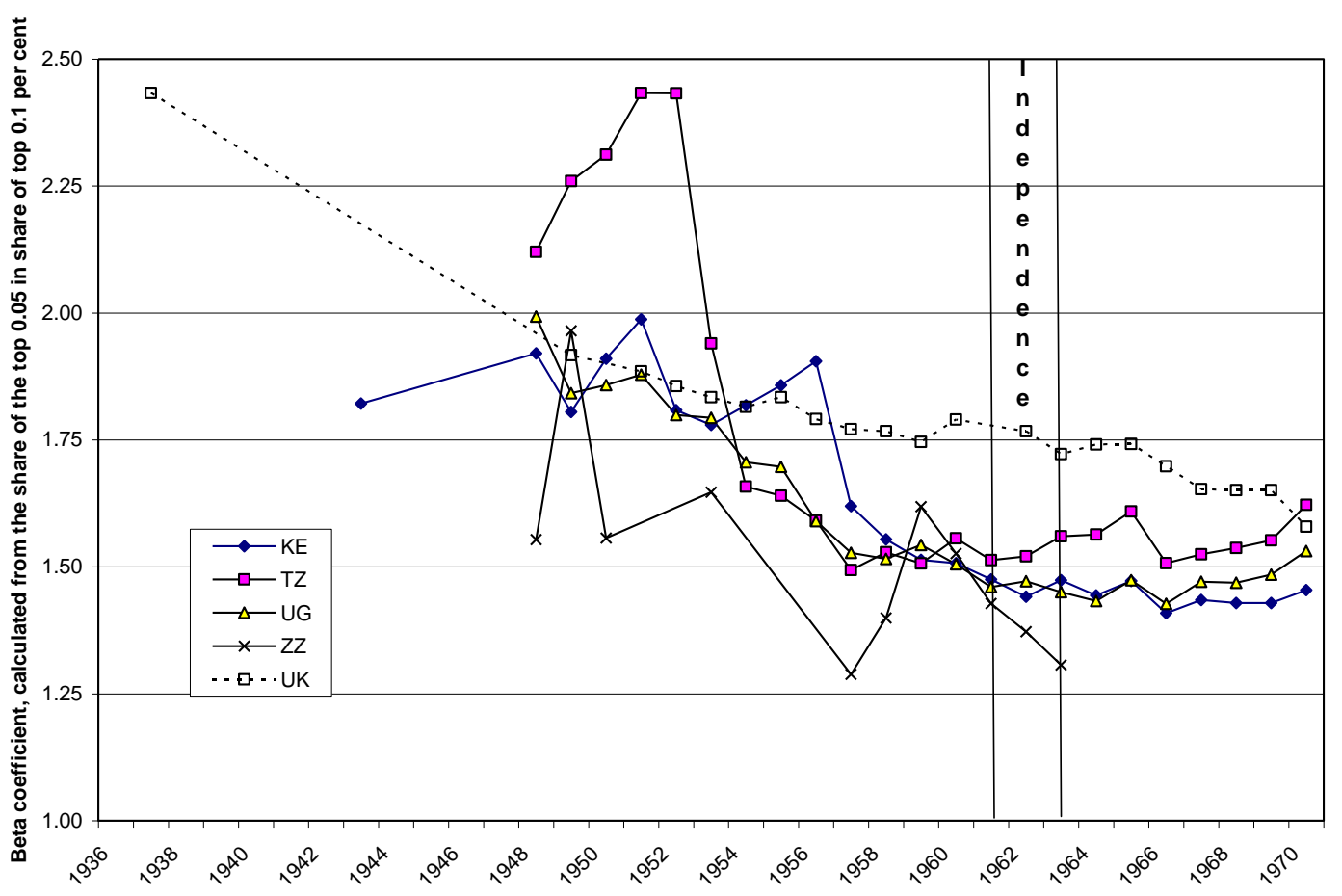

Source: calculated from the income tax sources listed in Appendix A and control totals in Appendix C. 
Figure 3 Zanzibar M curves

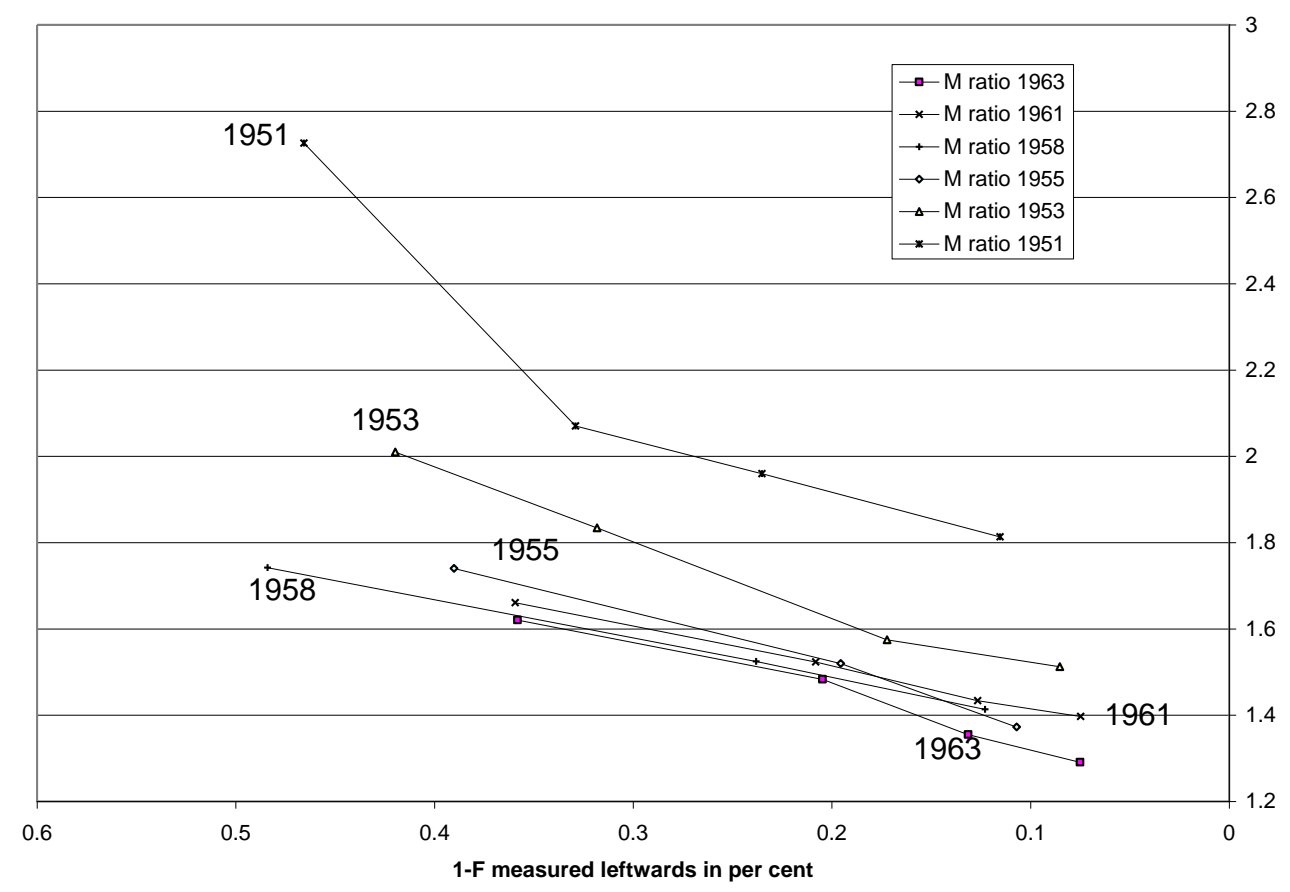

Source: from the income tax sources for Zanzibar listed in Appendix A and control totals in Appendix C. 
Figure 4 Kenya M curves after independence

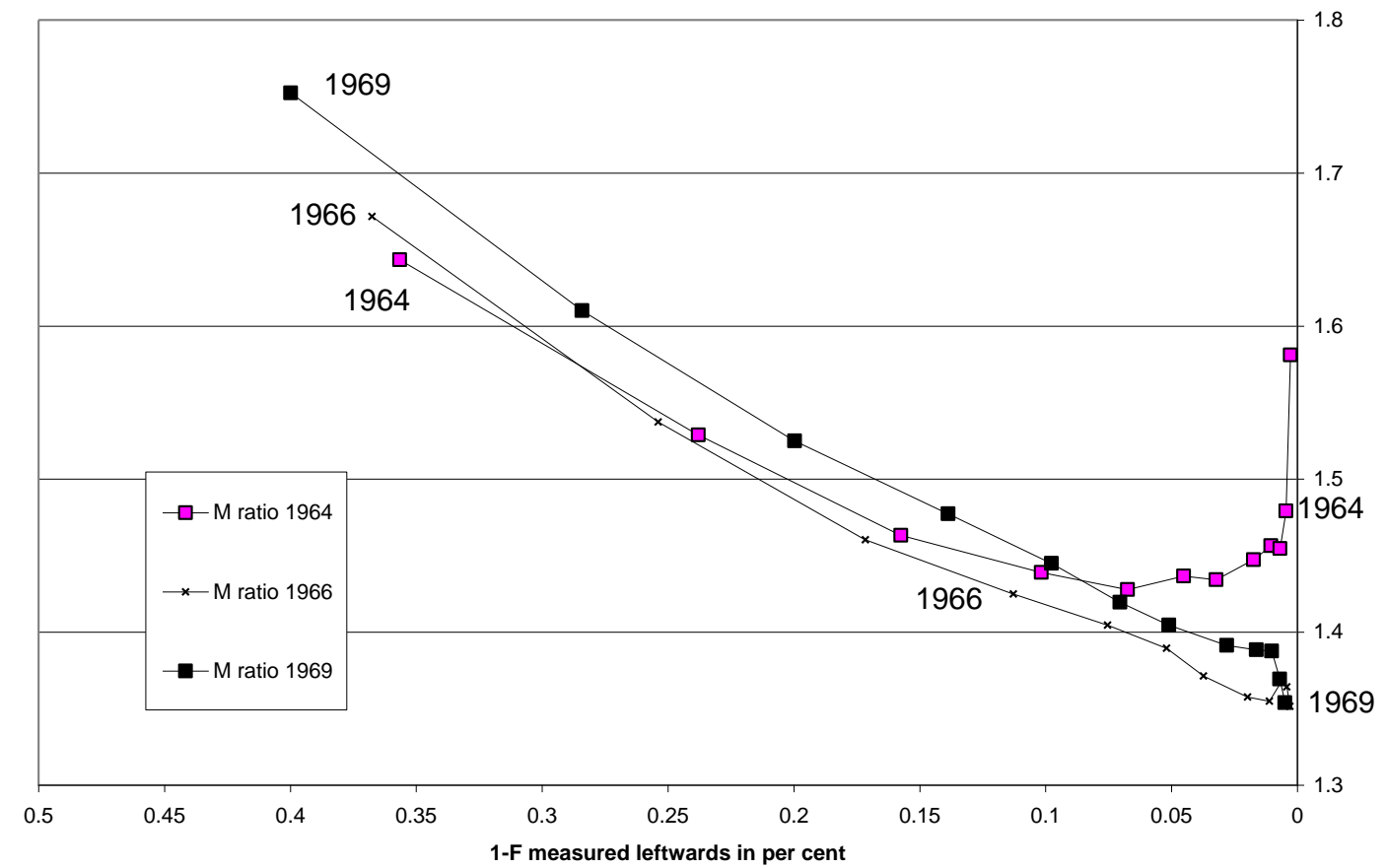

Source: from the income tax sources for Kenya listed in Appendix A and control totals in Appendix C. 
Figure $5 \mathrm{M}$ curves compared

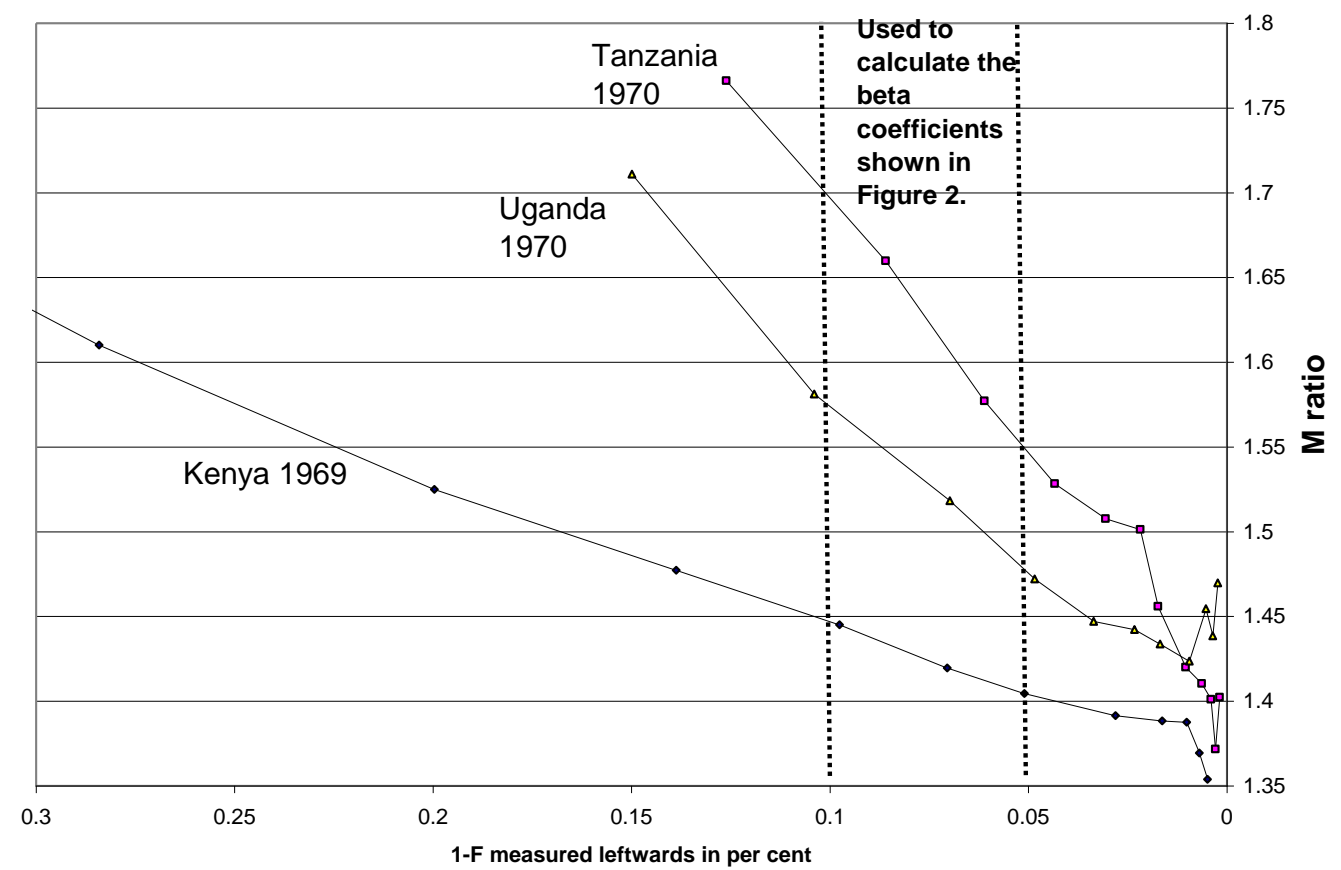

Source: from the income tax sources listed in Appendix A and control totals in Appendix C. 
Figure 6 Percentile 0.1 as per cent of mean

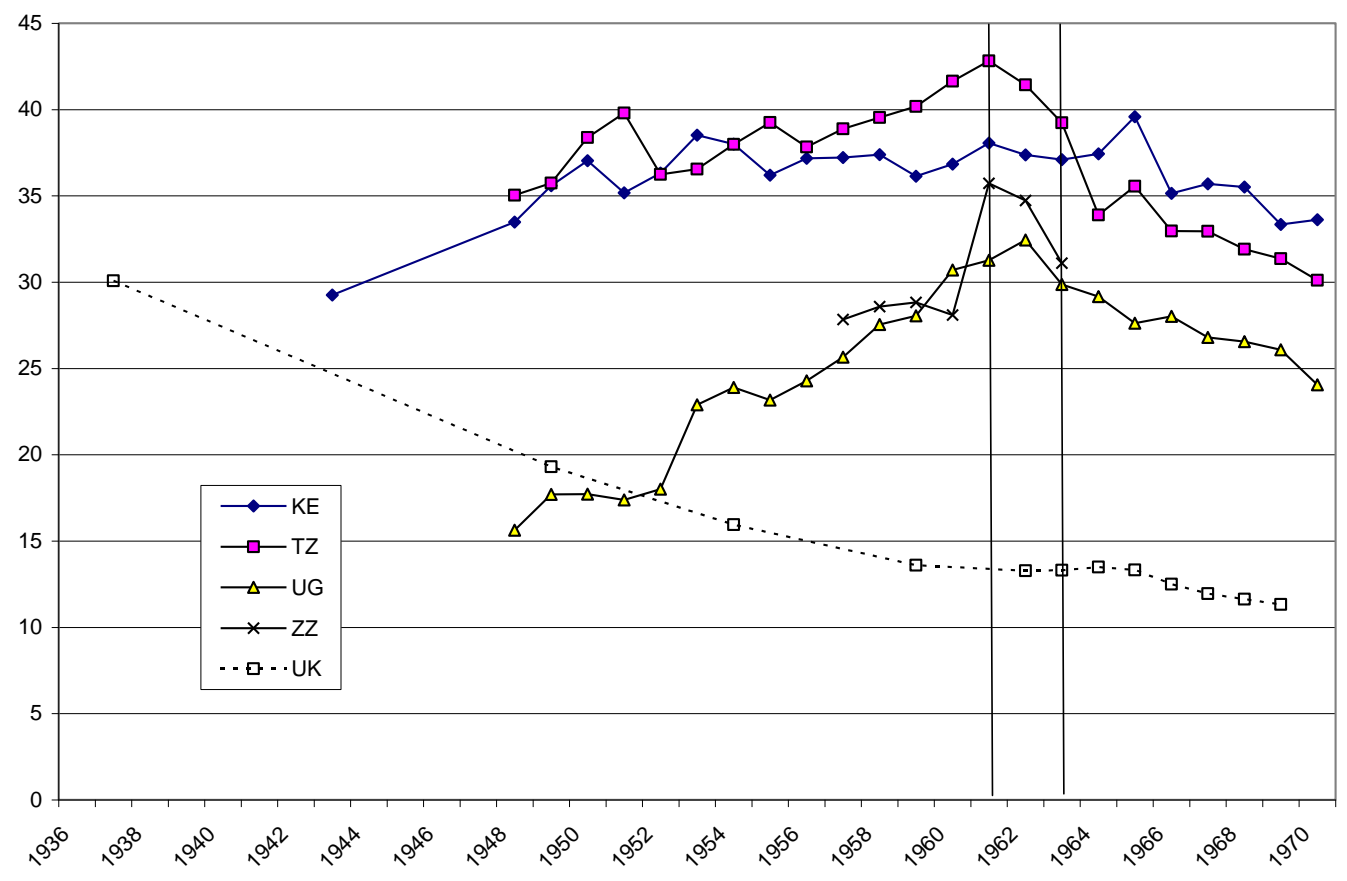

Source: from the income tax sources listed in Appendix A and control totals in Appendix C. 
Figure 7 Share of top 0.1 per cent

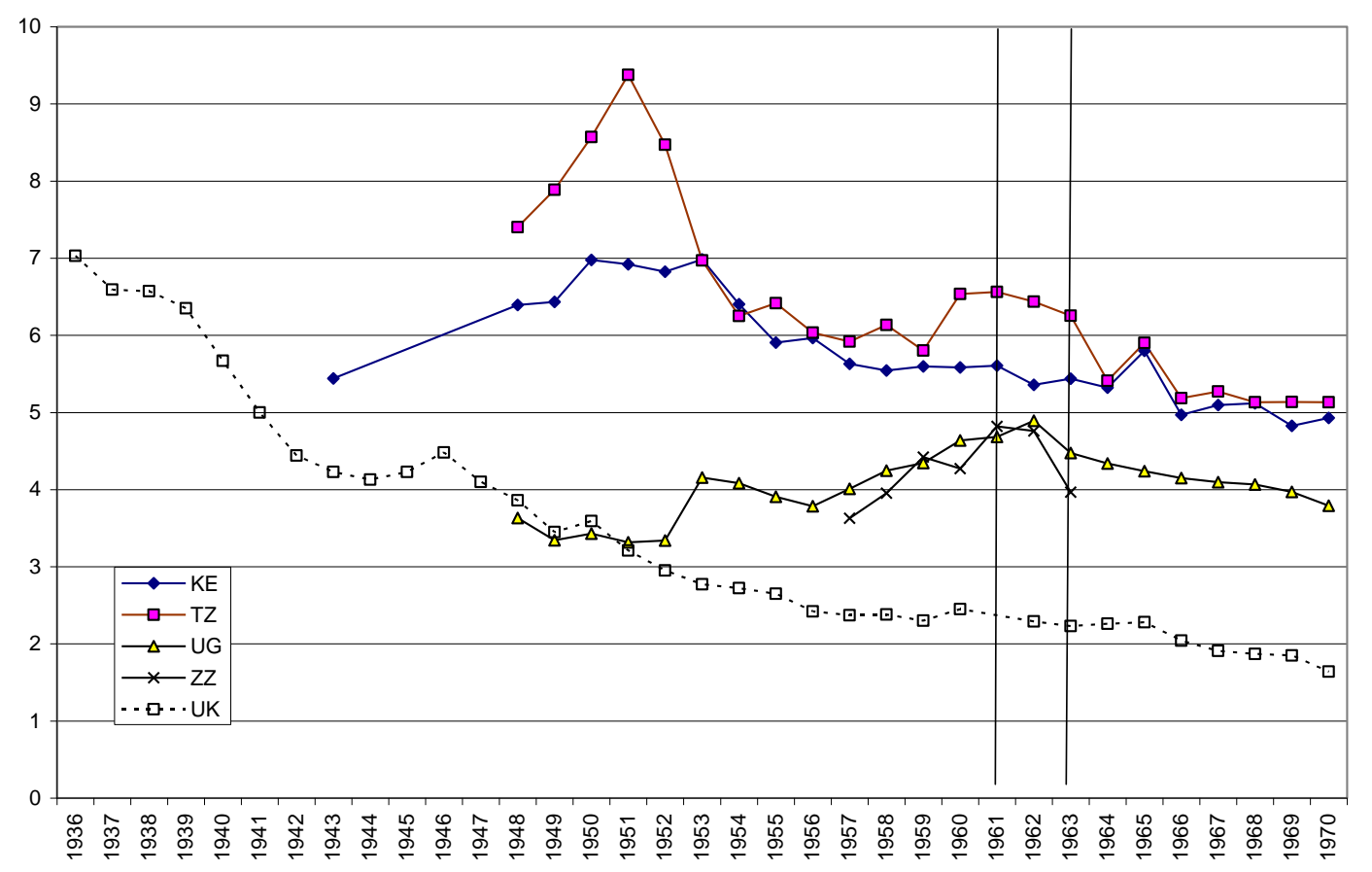

Source: from the income tax sources listed in Appendix A and control totals in Appendix C. 